\title{
Pleistocene to Holocene benthic foraminiferal assemblages from the Peruvian continental margin
}

\author{
Zeynep Erdem and Joachim Schönfeld
}

\begin{abstract}
The benthic foraminiferal inventory and their assemblage composition was documented along five sediment cores from the Peruvian margin between $3^{\circ} \mathrm{S}$ and $18^{\circ} \mathrm{S}$ at water depths of 500 to $1250 \mathrm{~m}$, covering the lower boundary of today's Oxygen Minimum Zone (OMZ). Emphasis was given to certain time intervals during the last 22 thousand years when different climatic and oceanographic conditions prevailed than today. In total three agglutinated and 186 calcareous species were recognised. Bolivina costata, Bolivinita minuta, Cassidulina delicata and Epistominella exigua were most abundant. The foraminiferal distributions revealed a marked change in assemblage composition particularly at the deeper cores during and after the deglaciation. The diversity declined and Bolivina species became dominant. These changes took place gradually over several millennia, and high-frequency fluctuations were not recorded. This pattern provides evidence for rather stable ecological conditions and sluggish changes in bottom water circulation during the last deglaciation.
\end{abstract}

Zeynep Erdem. NIOZ Royal Netherlands Institute for Sea Research, Texel, The Netherlands.

zeynep.erdem@nioz.nl

previously GEOMAR Helmholtz Centre of Ocean Research, Kiel, Germany

Joachim Schönfeld. GEOMAR Helmholtz Centre of Ocean Research, Kiel, Germany.

jschoenfeld@geomar.de

Keywords: benthic foraminifera; taxonomy; Peru; Oxygen Minimum Zone; Holocene; Deglaciation

Submission: 17 February 2017 Acceptance: 30 June 2017

\section{INTRODUCTION}

The present study focuses on benthic foraminifera from the continental margin off Peru in order to broaden our knowledge of Southeast Pacific foraminifera and their response to changing environmental conditions during the last glacialinterglacial transition. Today, the Peruvian margin is bathed by one of the strongest oxygen minimum zones (OMZs) in the world (e.g., Paulmier and Ruiz-Pino, 2009). Sediments underneath the Peruvian $\mathrm{OMZ}$ sustain rich foraminiferal faunas with a high population density and low diversity, similar to other oxygen depleted environments in the Arabian Sea or California borderland basins (Sen Gupta

Erdem, Zeynep and Schönfeld, Joachim. 2017. Pleistocene to Holocene benthic foraminiferal assemblages from the Peruvian continental margin. Palaeontologia Electronica 20.2.35A: 1-32

palaeo-electronica.org/content/2017/1929-benthic-foraminifera-off-peru 
and Machain-Castillo, 1993; Mallon et al., 2012; Cardich et al., 2015). The low-oxygen tolerant foraminiferal faunas are almost entirely composed of calcareous species (Gooday, 2003), because agglutinated species are less tolerant to hypoxic conditions and thus prefer oxygenated conditions (Bernhard and Sen Gupta, 1999; Gooday and Rathburn, 1999; Gooday et al., 2000; Levin et al., 2002). Large miliolids were also reported being restricted to higher bottom water oxygen concentrations (in Arabian Sea $>16 \mu \mathrm{mol} / \mathrm{kg}$; Caulle et al., 2014) and suggested as a proxy for rapid ventilation of oxygen-depleted environments (den Dulk et al., 2000). In particular, species of the family Bolivinitidae are tolerant to the suboxic conditions, and they occur in large numbers in the Peruvian OMZ (Phleger and Soutar, 1973; Khusid, 1974; Manheim et al., 1975; Ingle et al., 1980; Resig, 1981; Heinze and Wefer, 1992). Bolivina species, for instance, have shown an oxygen related distribution pattern (Mallon et al., 2012). Using this background information, we investigated the benthic foraminiferal distribution at different sediment cores recovered from the base of the Peruvian $\mathrm{OMZ}$ covering the last 22 thousand years. The aim of the study was to explore a) whether there are principle differences between Recent faunas and Pleistocene assemblages, b) the timing, frequency, and magnitude of faunal changes in the core records, and c) if and how they mirror changes in the climate and ocean systems during the last deglaciation.

Recent benthic foraminifera from the Peruvian and Chilean shelf and margin were previously documented by Bandy and Rodolfo (1964), Phleger and Soutar (1973), Khusid (1974), Ingle et al. (1980), Resig (1981), Resig (1990), Schönfeld and Spiegler (1995), Figueroa et al. (2005), Morales et al. (2006), Tapia et al. (2008), Cardich et al. (2012), Mallon (2012), Mallon et al. (2012), and Cardich et al. (2015). Some studies focused on living (rose Bengal stained) foraminiferal faunas (Tapia et al., 2008; Cardich et al., 2012; Mallon, 2012; Mallon et al., 2012; Cardich et al., 2015), but most of them considered dead or subfossil assemblages in nearsurface sediments. The records of Pleistocene and Holocene foraminiferal assemblages are limited to a few sediment cores, mostly from the centre of the OMZ. Only a few of those studies provided plates and detailed taxonomic references (Resig, 1990; Schönfeld and Spiegler, 1995).

Benthic foraminifera have served as important tools for palaeoenvironmental studies due to their global distribution, high levels of adaptation, short generation times, quick response to environmental changes, and good preservation of their tests in the fossil record (e.g., Alve and Bernhard, 1995; Van der Zwaan et al., 1999; Murray, 2006). They have been widely used in palaeoenvironmental reconstructions either by applying indicator species or groups (Lutze et al., 1986; Smart et al., 1994; Asteman and Nordberg, 2013; Alve et al., 2016), assemblage composition in general (Schmiedl et al., 2003; Jennings et al., 2004; de Nooijer, 2007; Mendes et al., 2012; Moffitt et al., 2014) or the elemental and isotopic chemistry of their shell calcite (e.g., Mackensen et al., 1993; Elderfield et al., 1996; Lear et al., 2000; Waelbroeck et al., 2002). This attribution of certain species and chemical response of their shell to environmental parameters has been the subject of a long and controversial debate (e.g., Van der Zwaan et al., 1999; Gooday, 2003). One of the biggest challenges of foraminiferal proxy studies is a correct and welldocumented taxonomy. Recent publications using benthic foraminifera as palaeoproxies rarely unveil the application of classical taxonomy methods, e.g., working strictly quantitative, preparing Plummer cell slides, providing high quality images, and annotated taxonomical reference lists quoting more than just the type references (Schönfeld et al., 2012). This process is lacking either because of time limitations during a project or because of the expenses to have access to classical taxonomy literature or the Ellis and Messina catalogues. Because of such limitations, we rely more and more on electronic sources, which eventually lead to mistakes in species determinations (Erdem, 2015). In this study, we therefore emphasised the taxonomic documentation by providing both, high quality optical and Scanning Electron microscope (SEM) images.

\section{REGIONAL SETTING}

The Peruvian continental margin is characterised by strong upwelling, high productivity, and pronounced oxygen minimum conditions in the water column. The oxygen minimum zones (OMZs) are defined as regions with dissolved oxygen concentrations of $<0.5 \mathrm{ml} / \mathrm{l}=\sim<22 \mu \mathrm{mol} / \mathrm{kg}$ (Helly and Levin, 2004; Fuenzalida et al., 2009). The Peruvian OMZ covers the continental slope and the shelf with its thickest part between $5^{\circ} \mathrm{S}$ and $15^{\circ} \mathrm{S}$ and 50 to $750 \mathrm{~m}$ water depths (Figure 1; Karstensen et al., 2008; Fuenzalida et al., 2009; Paulmier and RuizPino, 2009; Czeschel et al., 2012). The strength and extension of the Peruvian OMZ is maintained by the combination of a sluggish ocean circulation 

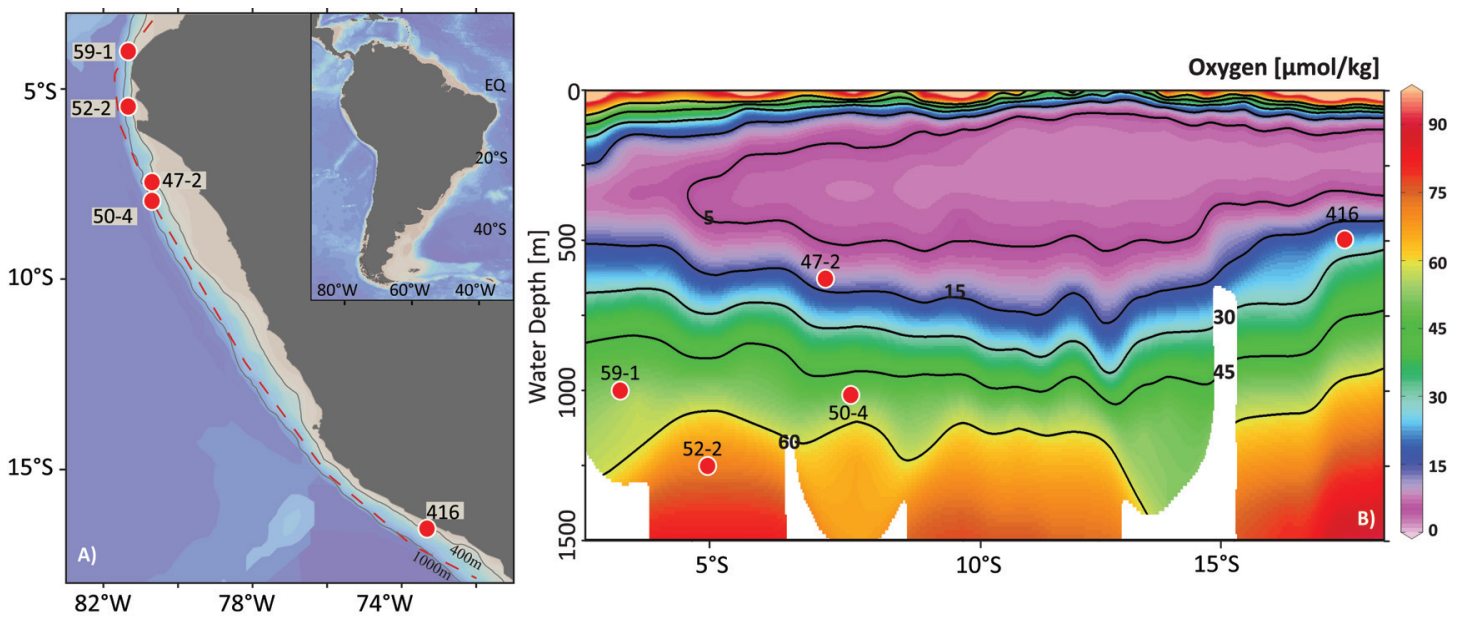

FIGURE 1. A) Map of the research area showing the core locations. The dashed line shows the approximate position of the section in $\mathrm{B}$ ) depth vs latitude section showing the dissolved oxygen concentrations and the core locations. Oxygen data were taken from a CTD compilation after Schönfeld et al. (2015). Contour lines indicate the dissolved oxygen concentration interval. Prepared by ODV Software (Schlitzer, 2010)

and high primary productivity in the surface waters, leading to increased organic carbon export and enhanced consumption of dissolved oxygen in the water column (Wyrtki, 1962; Fuenzalida et al., 2009; Schönfeld et al., 2015; Dale et al., 2015).

The Peruvian margin is tectonically active and the continental shelf extends down to about $600 \mathrm{~m}$ depth in places (Krissek et al., 1980; Strub et al., 1998). Between $7^{\circ} \mathrm{S}$ and $10^{\circ} 30^{\prime} \mathrm{S}$, the shelf is broad with a pronounced shelf break and a steep continental slope (Reimers and Suess, 1983; Suess et al., 1987; Reinhardt et al., 2002). Further south, between 11 and $14^{\circ} \mathrm{S}$, the shelf break is less pronounced (Reimers and Suess, 1983) and the shelf is narrower and deeper as compared to the northern part. The continental slope becomes steep again south of $15^{\circ} \mathrm{S}$ towards the Chilean margin, and the shelf is even narrower with a pronounced shelf break (Krissek et al., 1980). Due to these topographic alternations, the hydrodynamics of near-bottom waters play an important role for sedimentary processes at different latitudes and water depths. Active winnowing and reworking are observed in sediment cores obtained from the shelf between $11-14^{\circ} \mathrm{S}$ and from the slope south of $14^{\circ} \mathrm{S}$ (Reimers and Suess, 1983). The sedimentary record is characterised by marked unconformities and extended periods of non-deposition (Erdem et al., 2016). The sediments are predominantly olive green to dark grey green silts and clays with glauconitic sand and phosphorite layers. Laminations are observed within the $O M Z$ whereas around the $\mathrm{OMZ}$ foraminifera bearing, bioturbated silty clays are found (Pfannkuche et al., 2011). Sediments from intense upwelling areas south of $10^{\circ} 30^{\prime} S$ and within the $\mathrm{OMZ}$ are organic-rich, diatom bearing silty clays (Krissek et al., 1980; Suess et al., 1987; Wefer et al., 1990; Pfannkuche et al., 2011; Erdem et al., 2016). The sediment cores considered in the present study were obtained from the mid continental slope and from the lower oxic - suboxic boundary of the Peruvian OMZ between 500 and $1250 \mathrm{~m}$ depth where records with a longer stratigraphic reach or even continuous core sequences were found (Figure 1).

\section{MATERIALS AND METHODS}

In total, five sediment cores were considered in this study and they were recovered in 2008 during R/V Meteor cruise M77, Legs 1 and 2. They were located between $3^{\circ} \mathrm{S}$ and $18^{\circ} \mathrm{S}$ from water depths of $500 \mathrm{~m}$ to $1250 \mathrm{~m}$ (Table 1 and Figure 1). In reference to today's dissolved oxygen concentrations, the shallower two cores, core 47-2 and core 416, were located within the OMZ and other three cores, 59-1, 52-2, and 50-4, were located outside the OMZ (Figure 1). The sediment cores were split half, described and preliminary information was gathered on board (Pfannkuche et al., 2011). The age model of the core 59-1 was based on radiocarbon dating from planktonic foraminifera species Neogloboquadrina dutertrei performed at the Leibniz Laboratory for Radiometric Dating and Stable Isotope Research, University of Kiel (CAU). The ages were later calibrated applying the Marine09 marine calibration set (Reimer et al., 2009) with a reservoir age correction of $200 \pm 15$ 
TABLE 1. The metadata of the sediment cores used in this study.

\begin{tabular}{|c|c|c|c|c|c|c|}
\hline Cruise & Core name & Year & $\begin{array}{l}\text { Lat } \\
\text { (S) }\end{array}$ & $\begin{array}{l}\text { Long } \\
\text { (W) }\end{array}$ & $\begin{array}{l}\text { Water depth } \\
\text { (m) }\end{array}$ & Reference; Age model \\
\hline $\mathrm{M} 77 / 2$ & 059-PC1 & 2008 & $03^{\circ} 57.01^{\prime}$ & $81^{\circ} 19.23^{\prime}$ & 997 & Mollier-Vogel et al., 2013 \\
\hline $\mathrm{M} 77 / 2$ & 052-PC2 & 2008 & $05^{\circ} 29.01^{\prime}$ & $81^{\circ} 27.00^{\prime}$ & 1249 & Erdem et al., 2016 \\
\hline $\mathrm{M} 77 / 2$ & 047-PC2 & 2008 & $07^{\circ} 52.01^{\prime}$ & $80^{\circ} 31.36^{\prime}$ & 626 & Erdem et al., 2016 \\
\hline $\mathrm{M} 77 / 2$ & 050-PC4 & 2008 & $08^{\circ} 01.01^{\prime}$ & $80^{\circ} 30.10^{\prime}$ & 1013 & Erdem et al., 2016 \\
\hline M77/1 & 416-GC4 & 2008 & $17^{\circ} 28,13^{\prime}$ & $71^{\circ} 52,62^{\prime}$ & 505 & Erdem et al., 2016 \\
\hline
\end{tabular}

years (Mollier-Vogel et al., 2013). Age models of the other cores were based on radiocarbon dating of planktonic foraminifera species $N$. dutertrei (cores 52-2, 50-4 and 47-2) and benthic foraminifera species Planulina limbata (core 416) that were performed at the Beta Analytic Inc., Florida (Erdem et al., 2016). The ages were calibrated applying the Marine13 marine calibration set (Reimer et al., 2013). Reservoir age corrections were done according to the marine database (calib.qub.ac.uk/marine/) ranging from 89 to 338 years for this region (Erdem et al., 2016).

After the age models were established, they revealed rather incomplete records. Due to the erosion in the region and hiatus in the sedimentary record we were not able to compare all time intervals in all cores (Figure 2). The Last Glacial Maximum (LGM) was documented by four cores (52-2, $50-4,47-2$ and 416), the deglaciation was documented in northern part by four cores (59-1, 52-2, 50-4 and 47-1) whereas the Holocene was docu- mented only in the northernmost cores (59-1 and 52-2). We therefore focused on specific time intervals that are represented in as many cores as possible, in particular the Last Glacial Maximum (LGM; 20-22 cal ka BP), the Heinrich Stadial-1 (HS1; 1517.5 cal ka BP) the Bølling Allerød/Antarctic Cold Reversal (BA/ACR; 13-14.5 cal ka BP), the early Holocene (EH; 8-10 cal ka BP), and the late Holocene (LH; 3-5 cal ka BP) (Figure 2).

Volume-defined samples of 10 to $20 \mathrm{cc}$ were taken from the working halves of the cores at 10 $\mathrm{cm}$ spacing that corresponds to a resolution of 300 to 500 years. The samples were wet-sieved on a $63 \mu \mathrm{m}$ screen immediately after sampling, except for cores 47-2 and 59-1, which were sampled previously by others. The residues were oven-dried at $40^{\circ} \mathrm{C}$. They were later split with an Otto microsplitter in order to attain aliquots with a similar total number of ca. 300 specimens per sample (Murray, 2006). All benthic foraminifera from the $>63 \mu \mathrm{m}$ size fraction were dry picked from the aliquots, col-

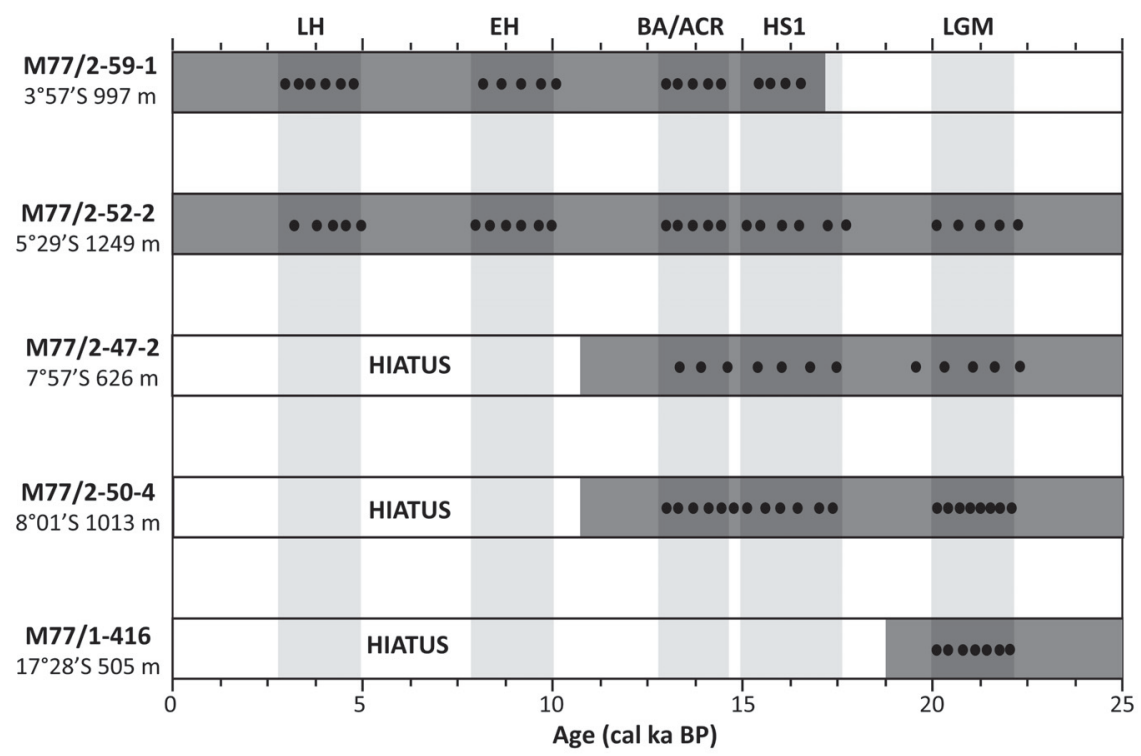

FIGURE 2. Schematic description of the focused time intervals and samples considered regarding to the benthic foraminifera study at each core. 

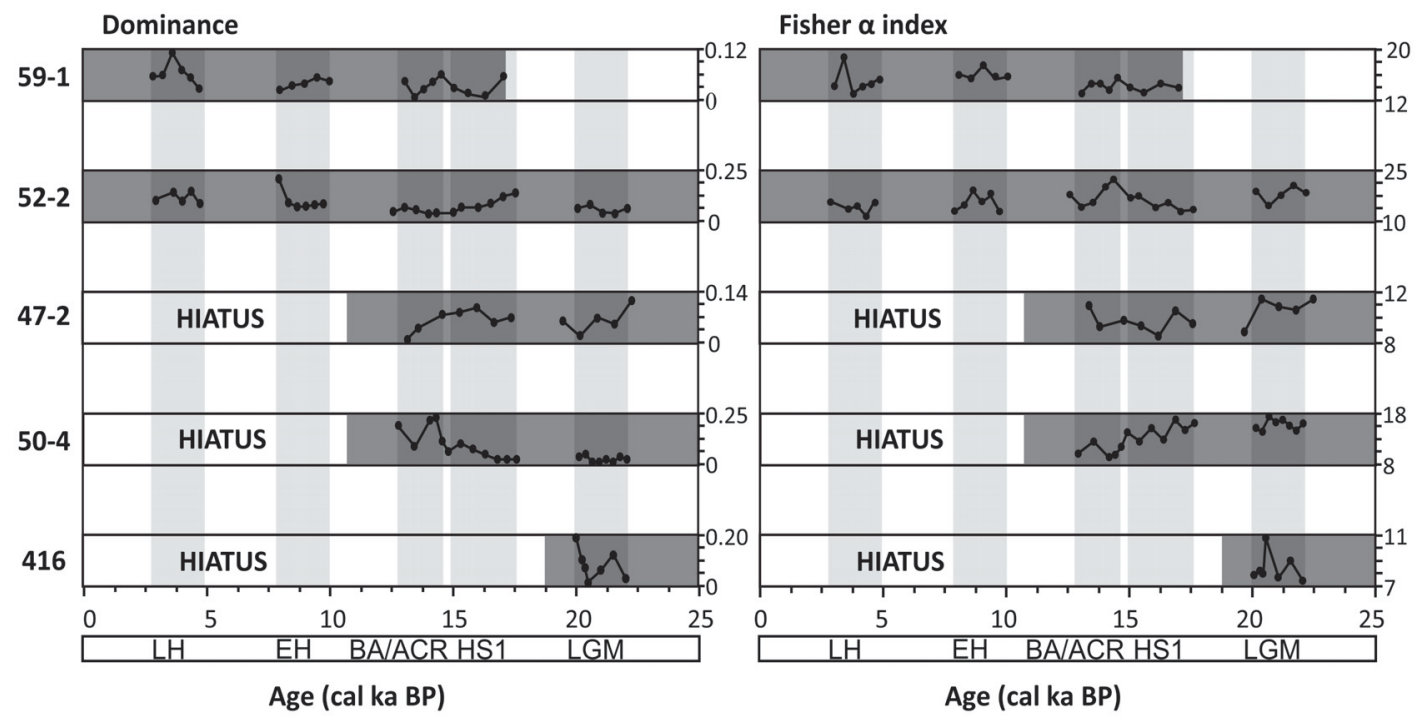

FIGURE 3. Dominance and Fisher $\alpha$ diversity indices calculated for each sample and core. Note that the scale bars are different.

lected in Plummer cell slides, sorted by species, fixed with glue and counted. The species were determined after Natland (1950); Barker (1960); Uchio (1960); Smith (1964); Boltovskoy and Theyer (1970); Coulbourn (1980); Ingle et al. (1980); Resig (1981); Loeblich and Tappan (1988); Whittaker (1988); Resig (1990); Figueroa et al. (2005); Mallon (2012), and the Ellis and Messina Catalogues. Relative abundances (\%) were calculated for each sample (Appendix). The most abundant species with $>5 \%$ relative abundance (Table 2) and common species that were observed in most of the cores (at least in three cores) were imaged with a CamScan 44/EDX scanning electron microscope and a Keyence VHX-700 FD digital camera at the Institute for Geosciences, Kiel University. The Fisher a diversity index and dominance was calculated from the census data using the software Palaeontological STatistics (PAST) Version 3.11 (Hammer et al., 2001). The Fisher a index assumes that the abundance of species follows the log series distribution and is calculated through the gradient of relationship between the number of species and individuals in a sample (Fisher et al., 1943).

\section{RESULTS}

A total of 189 species were identified in all the sediment cores. Three of them were agglutinated species (Dorothia goesii, Martinottiella communis, and $M$. nodulosa). They were observed only in the deep cores 59-1, 52-2, and 50-4. Relative abundances of the agglutinated species showed highest values in core 52-2 (up to $2.2 \%$ ) during the late Holocene and were less than $0.5 \%$ in other two cores (Appendix). Total relative abundance of the miliolids showed a similar trend (Pyrgo depressa, $P$. lucernula, $P$. murrhyna, $P$. serrata, Quinqueloculina seminulum, $Q$. triangularis). They were observed at a few samples with percentages less than $1.5 \%$ from the deep cores, predominantly during the LGM period, whereas in the shallow cores specimens of Quinqueloculina species were observed only at one sample in each core (47-2 and 416; Appendix). Overall, diversity was higher at the deeper cores 59-1, 52-2, and 50-4 as indicated by the Fisher $\alpha$ index (Figure 3 ). It showed values between 8 and 25 at these cores whereas at the shallower cores the values ranged from 7 to 11 and from 8 to 12 at core 416 and 47-2, respectively. The diversity showed a decreasing trend during the deglaciation at cores 47-2 and 50-4, from values 12 and 18 to around 8 . The dominance measured in all samples showed that certain time intervals were dominated by specific species. It showed different trends in each core. The highest values (up to 0.25) were observed at cores 50-4 and 52-2 during the deglaciation and the Holocene.

In the present study, we mainly focused on 38 common species with relative abundances of more than $5 \%$ observed at least at one sample in each core (Table 2). These species constitute at least $70 \%$ of whole benthic foraminiferal assemblages 
TABLE 2. List of the most abundant species with $>5 \%$ relative abundance observed in each sediment core. The most abundant and common species are indicated bold. * species without image.

\begin{tabular}{|c|c|c|c|c|c|}
\hline \multirow[b]{2}{*}{ Species name } & \multicolumn{5}{|c|}{ Occurrence } \\
\hline & $59-1$ & $52-2$ & $50-4$ & 47-2 & 416 \\
\hline Alabaminella weddellensis & $0-6$ & & & absent & absent \\
\hline Anomalinoides minimus & $0-5$ & & absent & & absent \\
\hline Bolivina costata & & $1-43$ & $5-45$ & $16-26$ & \\
\hline Bolivina interjuncta var. bicostata & $0-7$ & & & & $0-5$ \\
\hline Bolivina pacifica & $0-6$ & $0-5$ & $0-6$ & & \\
\hline Bolivina plicata & & absent & & & $0-6$ \\
\hline Bolivina quadrata* & $0-7$ & & absent & & absent \\
\hline Bolivina seminuda var. humilis & & & $1-7$ & $0-6$ & $1-23$ \\
\hline Bolivina spissa & $0-5$ & $0-7$ & & & absent \\
\hline Bolivinita minuta & $0-30$ & $0-20$ & $0-10$ & $0-6$ & \\
\hline cf Buccella peruviana & & & $0-5$ & $2-9$ & \\
\hline Bulimina exilis & & & $0-6$ & & \\
\hline Bulimina pagoda & & $0-7$ & & & absent \\
\hline Buliminella elegantissima & & & & & $0-22$ \\
\hline Cassidulina auka & absent & $0-6$ & $0-6$ & & $2-38$ \\
\hline Cassidulina carinata & $0-9$ & $0-24$ & $0-11$ & & \\
\hline Cassidulina delicata & $3-14$ & $5-21$ & $3-14$ & $6-16$ & \\
\hline Cassidulina laevigata* & & $0-14$ & & & absent \\
\hline Cassidulina minuta & $0-9$ & & & $0-9$ & absent \\
\hline Cibicides mckannai & & $0-7$ & & absent & absent \\
\hline Epistominella afueraensis & & & $0-7$ & & $0-27$ \\
\hline Epistominella exigua & $5-23$ & $0-33$ & $0-13$ & & $0-6$ \\
\hline Epistominella obesa* & $0-5$ & & $0-15$ & $2-16$ & \\
\hline Epistominella pacifica & $0-6$ & $0-8$ & $0-8$ & & $0-34$ \\
\hline Epistominella smithi & $0-6$ & $0-12$ & $0-7$ & absent & absent \\
\hline Fursenkoina fusiformis & & $0-5$ & $0-5$ & & \\
\hline Gyroidina rothwelli & $0-5$ & & & & $2-14$ \\
\hline Nonionella auris* & & & & & $0-15$ \\
\hline Planulina limbata & & & & & $0-7$ \\
\hline Pseudoparella sp. & & & $0-18$ & $4-14$ & absent \\
\hline Pseudoparella subperuviana* & & & $0-15$ & $3-14$ & $0-18$ \\
\hline Uvigerina auberiana & $0-8$ & $0-11$ & & & absent \\
\hline Uvigerina bifurcata & absent & $0-9$ & & absent & absent \\
\hline Uvigerina peregrina & & $0-10$ & & & $0-6$ \\
\hline Uvigerina semiornata & $0-5$ & $3-17$ & $0-7$ & & \\
\hline Uvigerina striata & & & & & $0-5$ \\
\hline Virgulina cornuta* & & & $0-6$ & & \\
\hline Virgulina spinosa & $0-21$ & absent & & absent & absent \\
\hline
\end{tabular}


in the samples (Appendix). This percentage drops to $60 \%$ in the samples from cores 59-1 and 52-2 where the Fisher $\alpha$ index showed relatively high values (Figure 3 ). The most abundant and common species observed in the cores are Bolivina costata, Bolivinita minuta, Cassidulina delicata, and Epistominella exigua. Overall trends showed that the most abundant taxa belong to the genera Bolivina, Cassidulina, Epistominella, and Uvigerina (Figure 4; Appendix).

On species level, these taxa showed differences between the sediment cores depending on the core location. In particular core 416, only the LGM is represented, was obtained from the southernmost and shallowest station. The distributional pattern was distinctly different from the other cores. Cassidulina auka showed highest percentages (up to $40 \%$ ) in this core whereas it was absent in all samples from core $59-1$ and less than $5 \%$ in other three cores (52-2, 50-4, and 47-2). Instead, C. delicata showed high percentages (up to $25 \%$ ) in the northern cores, particularly in core 59-1 ranging between 5 and $20 \%$. A similar difference was observed in the distribution of Bolivina costata. This species was observed with highest percentages ranging from 0 to $50 \%$ in the cores between latitudes 5-8 ${ }^{\circ} \mathrm{S}$ (cores 52-2, 50-4, and 47-2). Bolivina costata was observed at only one sample from core 416 and two samples from core 59-1. In core 59-1, other smaller Bolivina species, such as $B$. pacifica (Figure 4) and B. quadrata (Appendix) showed percentages reaching up to $6 \%$ during the deglaciation, particularly during the period BA/ $A C R$. Their abundance decreased to percentages around zero during the Holocene. In core 416, $B$. seminuda var. humilis represents the genus with percentages ranging from 0 to $30 \%$. Epistominella exigua was observed in all cores with highest percentages in the northern cores. Its abundance reached up to $25 \%$ in core $59-1,40 \%$ in core $52-2$ and $15 \%$ in core $50-4$ during the HS1. It showed a similar decreasing trend during the deglaciation in cores 50-4 and 52-2. Instead, Epistominella obesa and $E$. pacifica were more frequent in the shallower cores $47-2$ and 416 , respectively. Beside the differences between taxa from the same genus, some species showed high abundances and distinct differences between cores. Bolivinita minuta was observed in high numbers in the northern cores, showing an increase during the BA/ACR (Figure 4). At core 59-1, it remained the most abundant species throughout the Holocene with percentages reaching up to $30 \%$, whereas in core $52-2$, its abundance decreased distinctly from $20 \%$ in the
BA/ACR to $2 \%$ in the Holocene. Its abundance did not exceed $5 \%$ in core 416 similar to its distribution in other cores during the LGM. Pseudoparella subperuviana showed low percentages $(<5 \%)$ in the northern and deep cores 59-1 and 52-2, whereas its abundance reached up to $20 \%$ in other cores (Figure 4). Inversely, Uvigerina auberiana was abundant in the northern and deep cores, showing an increasing trend from the HS1 to LH with percentages ranging from 0 to $8 \%$ in core $59-1$ and from 0 to $15 \%$ in core 52-2. Uvigerina auberiana was low in abundance in cores 50-4 and 47-2, and absent from the southernmost core 416. In addition, the smaller species Anomalinoides minimus and Alabaminella weddellensis, which were not mentioned as common species in earlier studies, were found with proportions exceeding $5 \%$ in core 59-1 during the Holocene (Figure 5). Both species were absent in core 416 and not abundant in other cores. Buliminella elegantissima and Nonionella auris showed high abundances of $21 \%$ and 9-15 $\%$, respectively, in samples $140 \mathrm{~cm}$ and $180 \mathrm{~cm}$ from core 416 (Figure 6). They were absent from other samples of this core, and likewise were absent or did show only low numbers in other cores.

\section{DISCUSSION}

Benthic foraminifera generally show a low diversity and a high dominance in oxygen depleted environments (e.g., Phleger and Soutar, 1973; Sen Gupta and Machain-Castillo, 1993; Bernhard and Sen Gupta, 1999). The shallow cores $47-2$ and 416 were recovered from the edge of the modern OMZ and due to the erosion, observations regarding to the temporal variations was limited to LGM in core 416 and to LGM and the deglaciation in core 47-2. The dominance and diversity indices did not reveal distinct differences throughout the time intervals considered in core 47-1. However, the deeper core 50-4 from the same latitude indicated a distinct decrease in diversity and an increase in dominance during the deglaciation. This pattern might indicate a relatively stable bottom water oxygenation around today's $600 \mathrm{~m}$ water depth, and a thickening of the oxic-suboxic boundary in greater depths at these latitudes. On the other hand, the dominance and diversity measures from the northern cores indicated fluctuating trends during the deglaciation rather than a distinct diversity decline as in core 50-4. That trend in core 50-4 was mostly related to the relative abundance of Bolivina costata, which showed a distinct increasing trend during the deglaciation and reaching up to $45 \%$ of 

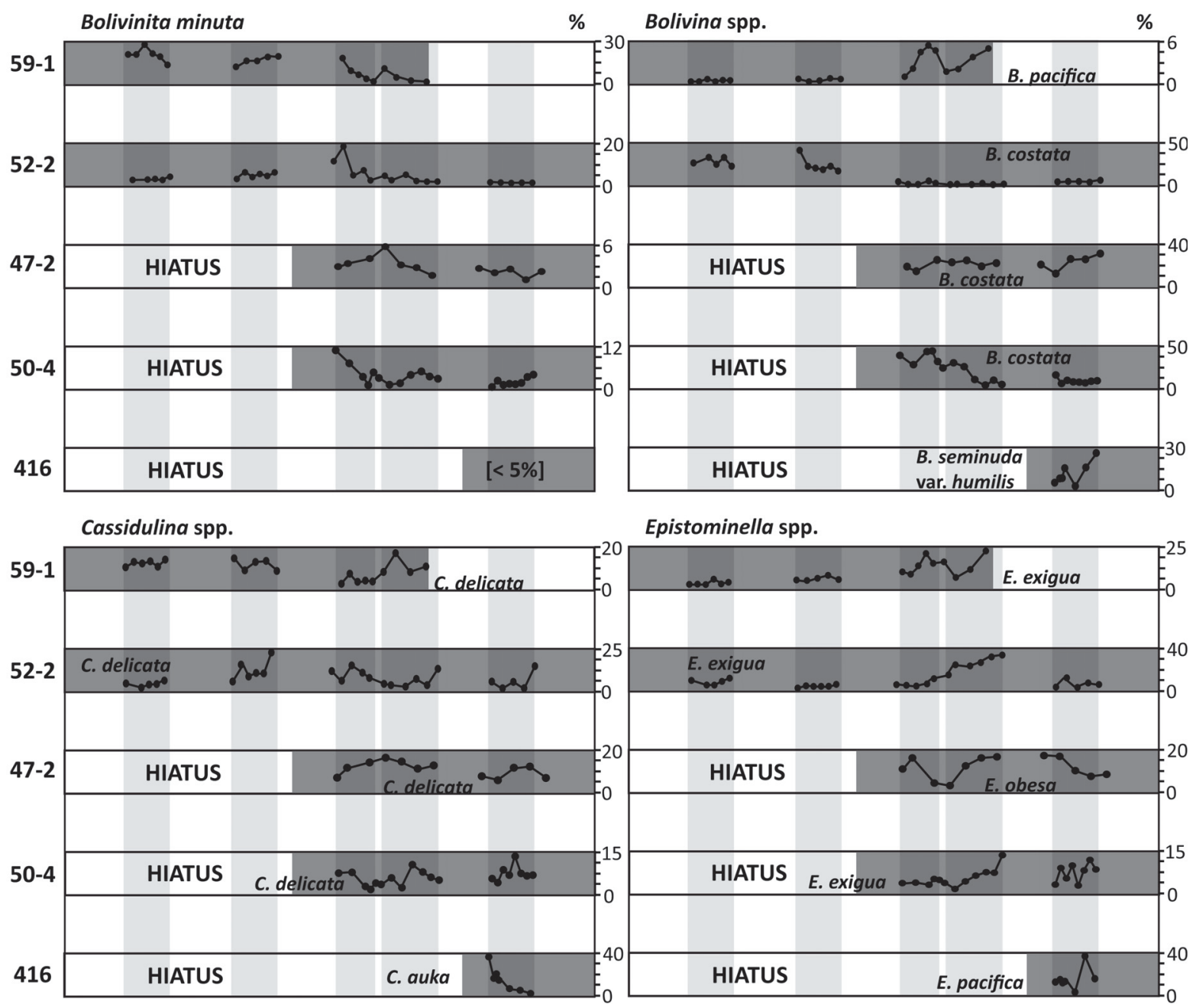

Epistominella spp.
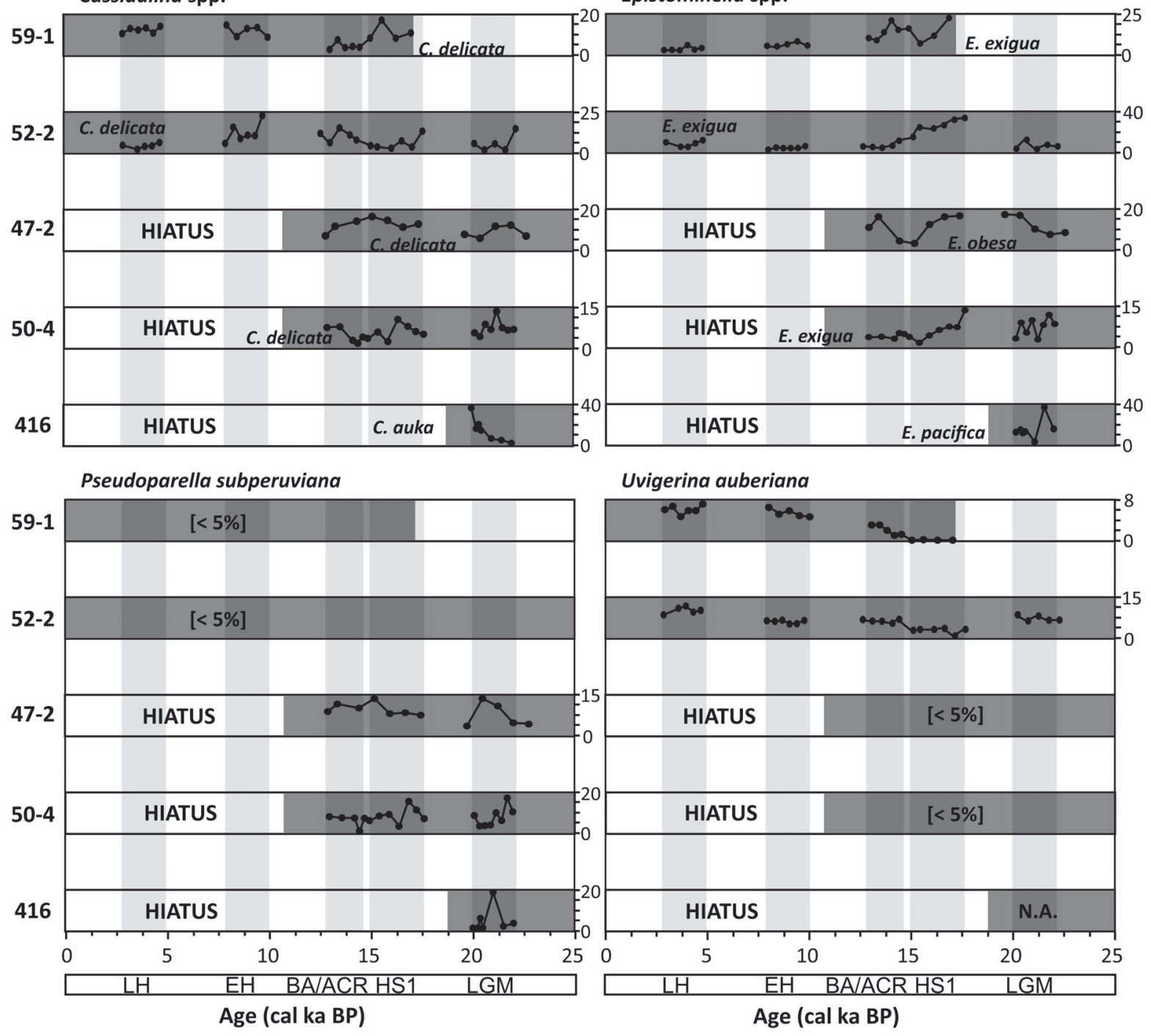

FIGURE 4. Downcore distributions of the most abundant species ( $>5 \%$ relative abundance) observed in the sediment cores. N.A.: in case of absence of the species. Note that the scale bars are different. 


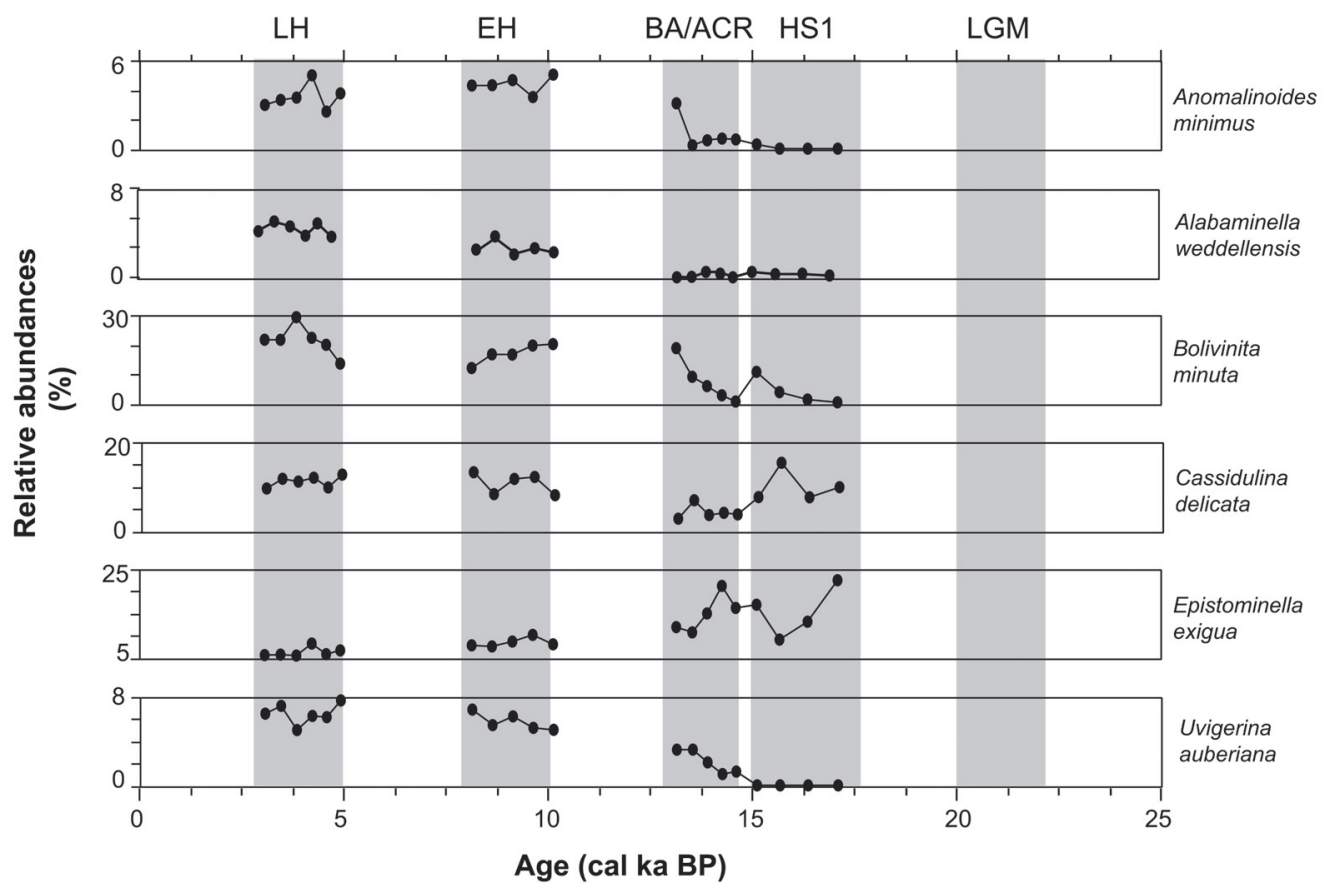

FIGURE 5. Downcore distributions of A. minimum, A. weddellensis, B. minuta, C. delicata, E. exigua and U. auberiana observed in core M77/1-59-1. Note that the scale bars are different.

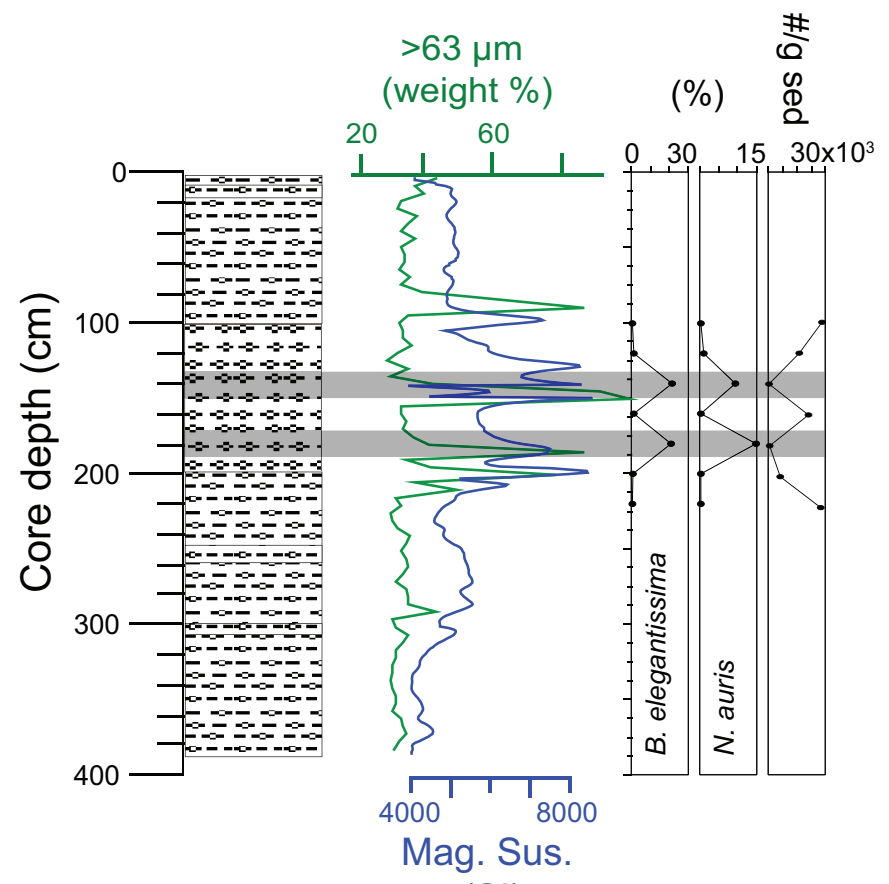

(SI)

FIGURE 6. Visual description of core M77/1-416 with magnetic susceptibility (SI) measurements and $<63 \mu \mathrm{m}$ (weight \%) information. Relative abundances of given species are potentially in relation with the downslope transported material. 
whole assemblage during the BA/ACR. In the core 52-2, however, Epistominella exigua reached up to $40 \%$ during the HS1 and dominated the whole assemblage, which is reflected in both, low diversity and high dominance.

In overall distributional patterns, Bolivina costata was one of the most abundant species, but its occurrence was limited to sediment cores between $5^{\circ} \mathrm{S}$ and $8^{\circ} \mathrm{S}$. Not much is known about the ecology of $B$. costata, as well as its distribution in the global oceans. Previous observations off Peru reported its tolerance to oxygen minimum conditions (Khusid, 1974; Resig, 1981; Mallon et al., 2012) and even to sulfidic pore waters (Cardich et al., 2015). Another downcore application from the Peruvian margin used this species as high upwelling and low oxygen indicator (Heinze and Wefer, 1992). Its distribution also has been thought to be limited to the continental shelf offshore Peru, where it has been used as a proxy for sea-level fluctuations (Resig, 1990). New observations on living (rose Bengal stained) benthic foraminifera from the region indicated that $B$. costata also occurred in the deeper parts of the Peruvian margin (Mallon, 2012). Its distribution in core 50-4 indicated an increasing trend from $10 \%$ to $45 \%$ during the deglaciation. The deeper core $52-2$ from $5^{\circ} \mathrm{S}$ revealed similar changes but during a later period, the Holocene (Figure 4). This species could be an indicator of the deoxygenation in the bottom waters at these core sites offering the conclusion of a gradually expanding $O M Z$ with the onset of the deglaciation. This is also supported by the disappearance of the miliolids and the agglutinated species in core 50-4 with the onset of the deglaciation (Appendix).

Epistominella exigua has been associated with pulsed supply of phytodetritus (Gooday, 1993; Smart et al., 1994; Thomas and Gooday, 1996). It was observed at few samples in shallow cores 47-2 and 416. The abundances increased during the deglaciation in the northern cores but with different magnitudes. It showed high abundances in core 52-2 during HS1 followed by a distinct decrease towards the end of the deglaciation. In contrast, the $E$. exigua abundance fluctuated around similar values during the whole deglaciation in the northernmost core 59-1. The southern core within these three cores, 50-4, showed a different pattern. The proportions of $E$. exigua fluctuated during the LGM indicating high detritus fluxes to the sea floor at this time. The following trend of high abundances during HS1 and decreasing proportions during the deglaciation shows similarities with the distribution in core 52-2 although with much less proportions. These temporal and proportional differences indicate that different surface water processes (e.g., upwelling, surface productivity) have taken place above the core locations since the LGM. The northern part of the $5^{\circ} \mathrm{S}$ might have been under influence of the Equatorial upwelling system instead of the Peruvian coastal upwelling. The significant drop of the E. exigua proportions in the core 52-2 and its continuous occurrence in core 59-1 during the BA/ACR could be interpreted as a northward shift of the upwelling cell and a subsequently high surface productivity during the deglaciation. Furthermore, the negative correlation trend, which is observed between abundances of $E$. exigua and Bolivinita minuta, deserves attention. Even though the ecology of the latter species is yet largely unknown, other Bolivinita species are always observed in association with sustained organic matter input (Sarkar and Gupta, 2014 and references therein). Bolivinita minuta is one of the common species in the OMZ on the shelf and tolerant to low bottom water oxygen conditions (Ingle et al., 1980; Resig, 1990; Mallon et al., 2012). The species is not, however, as abundant as Bolivina costata within the $\mathrm{OMZ}$ core (dissolved oxygen concentrations $<5 \mu \mathrm{mol} / \mathrm{kg}$; Mallon et al., 2012). Its slightly increasing trend at the end of the BA/ACR period is observed in all cores from the northern part of the region and could be related to environmental changes in relation to climatic changes during the Younger Dryas, which is often not observed in the Southern Hemisphere records (Broecker et al., 2010; Shakun and Carlson, 2010). Additionally, this slight increase is also in accordance with the distributional pattern of Anomalinoides minimus in core 59-1, which might be an indication of short-term ventilation at intermediate depths. Anomalinoides minimus was previously observed and described from the Mediterranean Sea (Vismara Schilling and Parisi, 1981). Its size does not exceed $150 \mu \mathrm{m}$. The distribution of $A$. minimus in the Mediterranean Sea was reported in co-occurrence with Epistominella exigua and Eponides pussillus and in association with sapropels suggesting a high recolonization potential of deep-sea areas following anoxic periods (Schmiedl et al., 2003 and references therein). In the open oceans, these small opportunistic species are reported as indicators of enhanced phytodetritus input to the sea floor (e.g., Gooday, 2003). Anomalinoides minimus co-occurred with Alabaminella weddellensis, Bolivinita minuta, and Uvigerina auberiana in the core 59-1 (Figure 5). The decreas- 
ing trend of $E$. exigua together with the increase of other species increased might be related to changes in food-composition or their (of $A$. weddellensis, B. minuta and $U$. auberiana) low tolerance of the low oxygenation in the bottom waters during the deglaciation. Epistominella exigua is potentially much more tolerant to low oxygen concentrations and may have benefited from less competition. High productivity and low bottom water oxygen conditions during the deglaciation were reported for the Eastern Equatorial Pacific (Pedersen, 1983; Hendy and Pedersen, 2006), which supports this idea. It should also be kept in mind that core 59-1 has been under the influence of major riverine input (Mollier-Vogel et al., 2013). According to their results, the terrestrial input decreased during the deglaciation and increased during the late Holocene. Since the benthic foraminiferal information is not continuous, we cannot assess the influence of terrestrial material with certainty.

Cassidulina delicata is one of the common species of upper-middle bathyal assemblages (500-1 $000 \mathrm{~m}$ ) offshore Peru and Chile (Ingle et al., 1980; Resig, 1981) and offshore California (Bandy, 1953; Zalesny, 1959; Uchio, 1960). It occurred dominantly together with Epistominella pacifica, E. smithi, and Bolivinita minuta. Off Chile, Ingle et al. (1980) related this assemblage to the influence of Antarctic Intermediate Waters (AAIW). Cassidulina delicata is also reported as low oxygen tolerant species (Douglas and Heitman, 1979; Sen Gupta and Machain-Castillo, 1993). In our core samples, $C$. delicata is one of the most abundant species and our findings agree with the previous observations. It was observed with percentages more than $5 \%$ in all cores except core 416 . Nonetheless, $C$. delicata did not show distinct changes along the cores, and thus the species' distribution was seemingly not influenced by the same environmental factors as the other species.

The recent occurrence of Buliminella elegantissima and Nonionella auris is known to be limited to the continental shelf (e.g., Ingle et al., 1980; Resig, 1990; Mallon, 2012). Comparing their abundances with sedimentological information and physical properties measured at core 416, it emerged that their occurrence matched with levels showing evidences of re-deposition (Figure 6). In particular, high values of magnetic susceptibility (SI) together with an increase in sand content (weight $\%>63 \mu \mathrm{m}$ ) at the same core depths were considered as indicators of the downslope transport. The foraminiferal data from these core depth levels should therefore be taken with caution.

\section{CONCLUSIONS}

Five sediment cores from the lower boundary of the Peruvian OMZ were investigated with emphasis on certain time intervals during the last 22 thousand years. Benthic foraminiferal inventory and assemblage composition of the size fraction $>63 \mu \mathrm{m}$ was assessed throughout the considered time intervals. In total, 189 species were identified. The most abundant species were Bolivina costata, Bolivinita minuta, Cassidulina delicata, and Epistominella exigua. The assemblage composition did not show abrupt changes or fluctuations during the periods studied. The most distinct changes were increasing relative abundances of $B$. costata and $B$. minuta in the deeper cores during and after the deglaciation, suggesting a gradual decrease of bottom water ventilation. The overall faunal changes were gradual providing evidence for relatively stable ecological conditions along the Peruvian margin at intermediate water depths since the LGM.

\section{TAXONOMIC REFERENCE LIST}

Type references are given for each species identified. Angular brackets refer to figures.

Alabaminella weddellensis = Eponides weddellensis Earland, 1936. [Figures 7.12, 8.24].

Angulogerina angulosa = Uvigerina angulosa (Williamson, 1858). [Figure 9.4].

Angulogerina carinata (Cushman, 1927).

Anomalinoides minimus (Vismara Schilling and Parisi, 1981). [Figures 7.4-5, 8.14, 8.20].

Bolivina advena (Cushman, 1925).

Bolivina advena Cushman var. striatella Cushman, 1925.

Bolivina alata = Valvulina alata (Seguenza, 1862).

Note: This species was denominated as Bolivina pseudobeyrichi Cushman and the species name Bolivina alata (Seguenza) is considered to have priority. [Figures 10.10, 11.10].

Bolivina albatrossi Cushman, 1922.

Bolivina argentea Cushman, 1926a. [Figure 10.5].

Bolivina costata d'Orbigny, 1839. [Figures 12.1, 8.8].

Bolivina doniezi Cushman and Wickenden, 1929.

Bolivina interjuncta = Bolivina costata d'Orbigny var. interjuncta Cushman, 1926a. [Figures 10.1, 11.1].

Bolivina interjuncta Cushman var. bicostata = Bolivina costata d'Orbigny var. bicostata Cushman, 1926a, illustrated in Cushman, 1937.

Note: The description and images provided by Uchio (1960) as Bolivina subargentea are also similar to what is observed in the sediment samples in this study, but the specimens observed in the sediment cores are too small in size compared to those reported by Uchio (1960). The appearance and struc- 


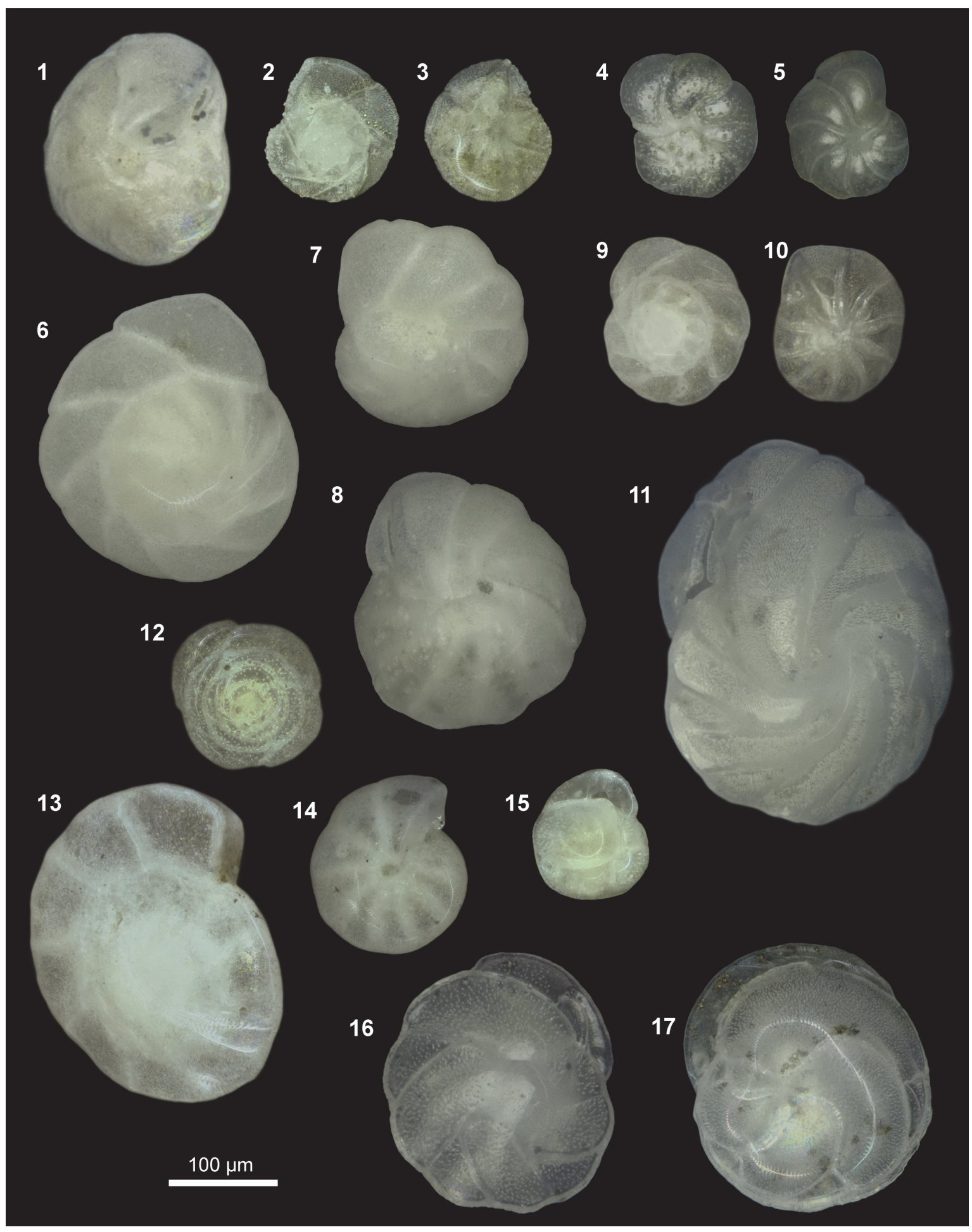

FIGURE 7. Optical microscope images; scale bar equals $100 \mu \mathrm{m}$. 1. Epistominella pacifica umbilical view 47-2; 128 $\mathrm{cm}, 2$. Epistominella exigua spiral view $52-2 ; 450 \mathrm{~cm}, 3$. Epistominella exigua umbilical view 52-2; $450 \mathrm{~cm}, 4$. Anomalinoides minimus spiral view 59-1; $523 \mathrm{~cm}, 5$. Anomalinoides minimus umbilical view 59-1; $523 \mathrm{~cm}, 6$. Epistominella obesa spiral view 50-4; $100 \mathrm{~cm}, 7$. Epistominella obesa spiral view 50-4; $100 \mathrm{~cm}, 8$. Epistominella obesa umbilical view 50-4; $100 \mathrm{~cm}, 9$. cf. Buccella peruviana spiral view 50-4; $230 \mathrm{~cm}$, 10. cf. Buccella peruviana umbilical view 47-2; $113 \mathrm{~cm}, 11$. Cassidulina auka 416; $100 \mathrm{~cm}, 12$. Alabaminella weddellensis spiral view 52-2; $270 \mathrm{~cm}, 13$. Gyroidina subtenera spiral view 52-2; $270 \mathrm{~cm}, 14$. Gyroidina subtenera umbilical view 52-2; $230 \mathrm{~cm}, 15$. Cassidulina minuta $52-$ 2; $120 \mathrm{~cm}, 16$. Cassidulina carinata $50-4 ; 210 \mathrm{~cm}, 17$. Cassidulina delicata 47-2; $128 \mathrm{~cm}$. 


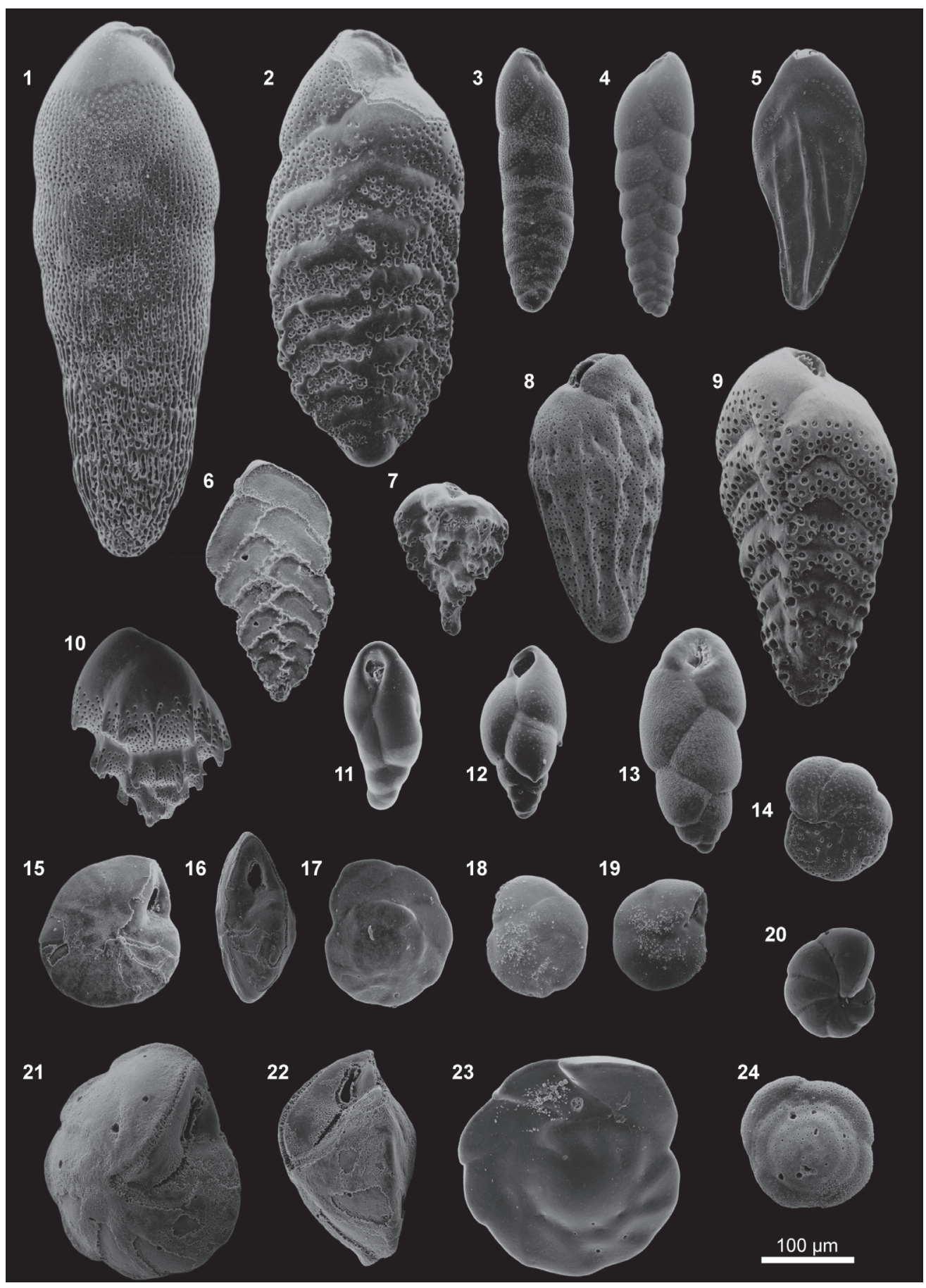

FIGURE 8. SEM images; scale bar equals $100 \mu \mathrm{m}$. 1. Bolivina seminuda 416; $200 \mathrm{~cm}$, 2. Bolivina cf. seminuda var. humilis 416; $200 \mathrm{~cm}$, 3. Bolivina seminuda var. humilis 47-2; $113 \mathrm{~cm}$, 4. Bolivina pacifica 52-2; $270 \mathrm{~cm}, 5$. Bolivina interjuncta var. bicostata 52-2; $520 \mathrm{~cm}, 6$. Bolivinita minuta 52-2; $270 \mathrm{~cm}, 7$. Bolivina aff. tortuosa 59-1; 523 cm, 8. Bolivina costata 52-2; $270 \mathrm{~cm}, 9$. Bolivina ordinaria 47-2; $128 \mathrm{~cm}, 10$. Bulimina pagoda 52-2; $520 \mathrm{~cm}$, 11. Fursenkoina fusiformis 50-4; $230 \mathrm{~cm}, 12$. Virgulina spinosa 59-1; $963 \mathrm{~cm}, 13$. Fursenkoina glabra 50-4; $230 \mathrm{~cm}$, 14. Anomalinoides minimus spiral view 59-1; $523 \mathrm{~cm}, 15$. cf. Buccella peruviana umbilical view $47-2 ; 113 \mathrm{~cm}, 16$. cf. Buccella peruviana peripheral view 47-2; $113 \mathrm{~cm}$, 17. cf. Buccella peruviana spiral view 50-4; $230 \mathrm{~cm}$, 18. Epistominella exigua spiral view $52-2 ; 450 \mathrm{~cm}, 19$. Epistominella exigua umbilical view 52-2; $450 \mathrm{~cm}$, 20. Anomalinoides minimus umbilical view 59-1; $523 \mathrm{~cm}, 21$. Epistominella afueraensis umbilical view 416; $200 \mathrm{~cm}, 22$. Epistominella afueraensis peripheral view 416; $200 \mathrm{~cm}, 23$. Epistominella afueraensis spiral view 416; $200 \mathrm{~cm}, 24$. Alabaminella weddellensis spiral view $52-2 ; 270$ $\mathrm{cm}$. 


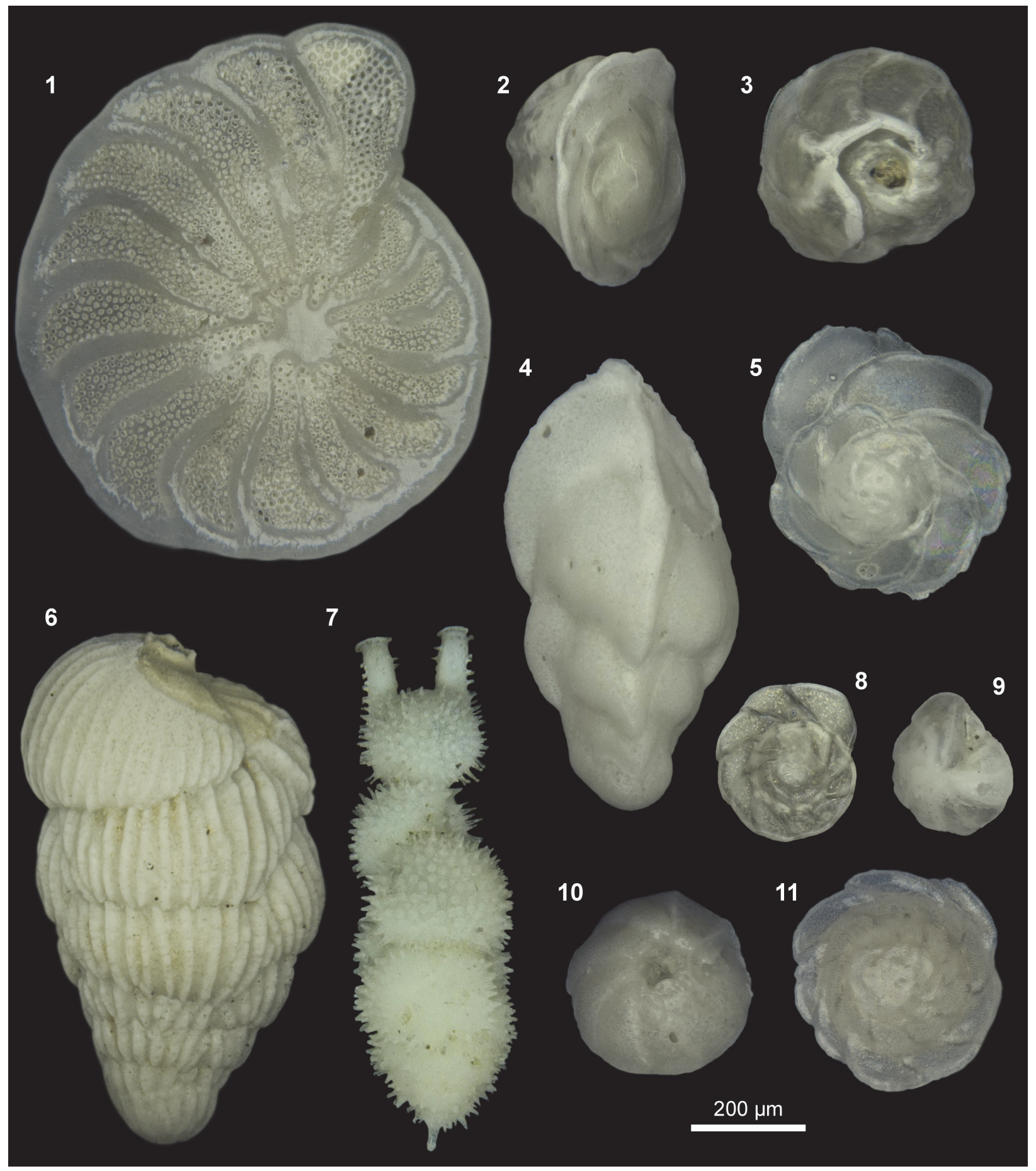

FIGURE 9. Optical microscope images; scale bar equals $200 \mu \mathrm{m}$. 1. Planulina limbata umbilical view $416 ; 100 \mathrm{~cm}, 2$. Epistominella pacifica 416; $200 \mathrm{~cm}$, 3. Epistominella pacifica umbilical view 416; $200 \mathrm{~cm}, 4$. Angulogerina angulosa 50-4; $100 \mathrm{~cm}, 5$. Epistominella smithi spiral view 50-4; $210 \mathrm{~cm}, 6$. Uvigerina striata 416; $200 \mathrm{~cm}, 7$. Uvigerina hispida 52-2; $120 \mathrm{~cm}, 8$. Epistominella afueraensis spiral view 416; $200 \mathrm{~cm}$, 9. Epistominella afueraensis umbilical view 416 ; $200 \mathrm{~cm}, 10$. Gyroidina rothwelli umbilical view 416; $100 \mathrm{~cm}, 11$. Gyroidina rothwelli spiral view $416 ; 100 \mathrm{~cm}$. 


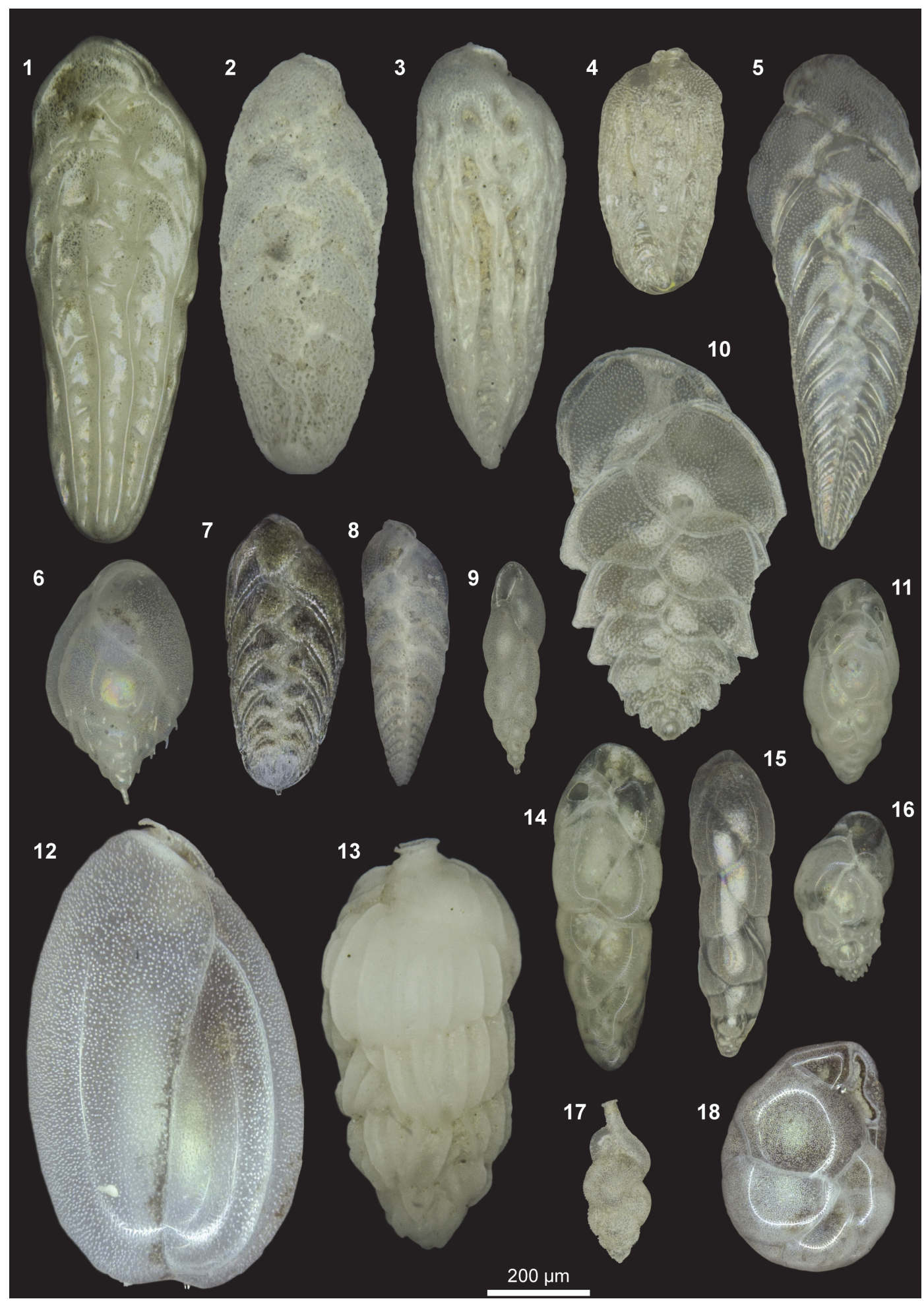

FIGURE 10. Optical microscope images; scale bar equals $200 \mu \mathrm{m}$. 1. Bolivina interjuncta 47-2; $168 \mathrm{~cm}, 2$. Bolivina subadvena 47-2; $113 \mathrm{~cm}, 3$. Bolivina plicata microspheric form 416; $200 \mathrm{~cm}$, 4. Bolivina plicata macrospheric form 416; $100 \mathrm{~cm}, 5$. Bolivina argentea 50-4; $350 \mathrm{~cm}, 6$. Praeglobobulimina spinescens 47-2; $168 \mathrm{~cm}, 7$. Bolivina spissa macrospheric form 52-2; $520 \mathrm{~cm}$, 8. Bolivina spissa microspheric form 47-2; $128 \mathrm{~cm}$, 9. Stainforthia complanata 50-4; $210 \mathrm{~cm}, 10$. Bolivina alata 50-4; $110 \mathrm{~cm}, 11$. Buliminella tenuata 50-4; $100 \mathrm{~cm}, 12$. Globobulimina pacifica $52-2 ; 230$ $\mathrm{cm}$, 13. Uvigerina peregrina 416; $200 \mathrm{~cm}, 14-15$. Bulimina exilis $50-4 ; 100 \mathrm{~cm} \& 350 \mathrm{~cm}$, 16. Buliminella curta var. basispinata 50-4; $350 \mathrm{~cm}, 17$. Uvigerina auberiana $50-4 ; 350 \mathrm{~cm}, 18$. Cassidulina crassa $52-2 ; 520 \mathrm{~cm}$. 


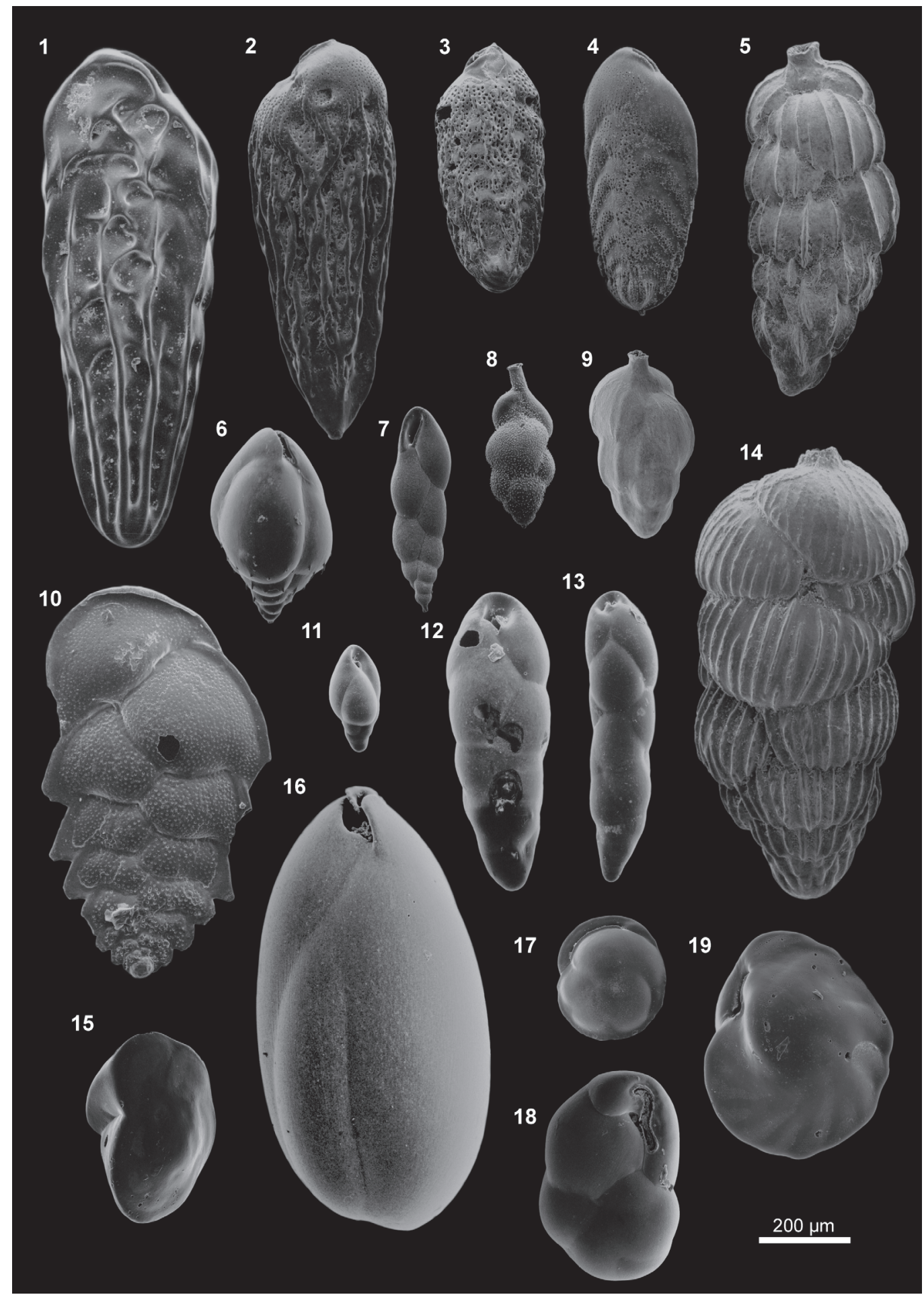

FIGURE 11. SEM images; scale bar equals $200 \mu \mathrm{m}$. 1. Bolivina interjuncta 47-2; $168 \mathrm{~cm}$, 2. Bolivina plicata microspheric form 416; $200 \mathrm{~cm}$, 3. Bolivina plicata macrospheric form 416; $100 \mathrm{~cm}$, 4. Bolivina spissa $52-2 ; 520 \mathrm{~cm}, 5$. Uvigerina peregrina 416; $200 \mathrm{~cm}$ (different specimen depicted in optical microscope and SEM image), 6. Praeglobobulimina spinescens 47-2; $168 \mathrm{~cm}, 7$. Stainforthia complanata 50-4; $210 \mathrm{~cm}$, 8. Uvigerina auberiana 50-4; $350 \mathrm{~cm}, 9$. Uvigerina semiornata 52-2; $230 \mathrm{~cm}, 10$. Bolivina alata 50-4; $110 \mathrm{~cm}, 11$. Buliminella cf. curta $50-4 ; 100 \mathrm{~cm}$, 12.-13 Bulimina exilis 50-4; $100 \mathrm{~cm} \& 350 \mathrm{~cm}, 14$. Uvigerina striata 416; $200 \mathrm{~cm}$, 15. Hoeglundina elegans $52-2 ; 500$ $\mathrm{cm}, 16$. Globobulimina pacifica 52-2; $230 \mathrm{~cm}, 17$. Cassidulina delicata 47-2; $128 \mathrm{~cm}$, 18. Cassidulina crassa $52-2 ; 520$ $\mathrm{cm}, 19$. Cassidulina auka 416; $100 \mathrm{~cm}$. 


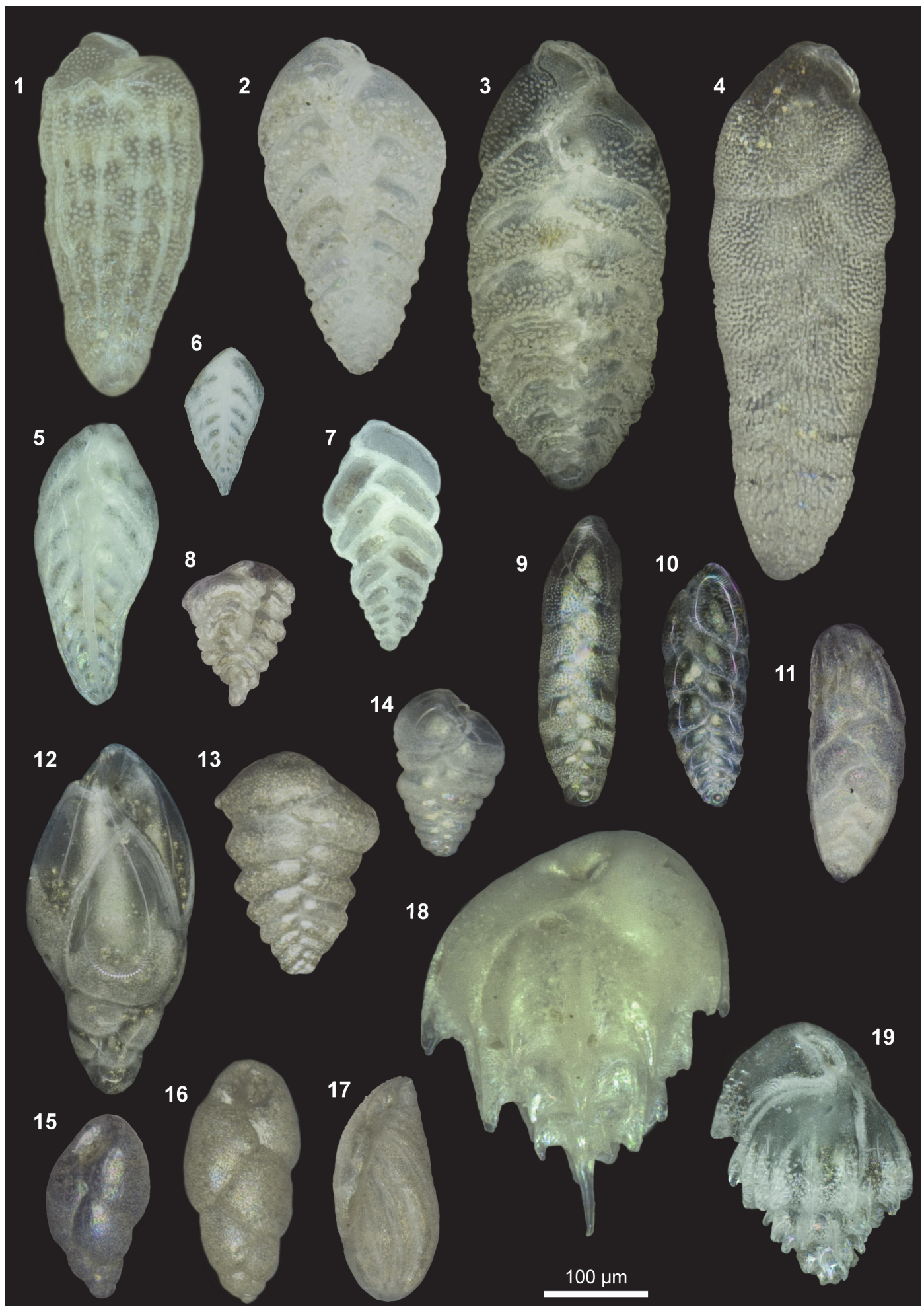

FIGURE 12. Optical microscope images; scale bar equals $100 \mu \mathrm{m}$. 1. Bolivina costata $52-2 ; 270 \mathrm{~cm} 2$. Bolivina ordinaria 47-2; $128 \mathrm{~cm}$, 3. Bolivina cf. seminuda var. humilis 416; $200 \mathrm{~cm}$, 4. Bolivina seminuda 416; $200 \mathrm{~cm}, 5-6$. Bolivina interjuncta var. bicostata 52-2; $520 \mathrm{~cm}$ and $450 \mathrm{~cm}, 7$. Bolivinita minuta $52-2 ; 270 \mathrm{~cm}, 8$. Bolivina aff. tortuosa $59-1$; $523 \mathrm{~cm}, 9$. Bolivina seminuda var. humilis $47-2 ; 113 \mathrm{~cm}, 10$. Bolivina pacifica $52-2 ; 270 \mathrm{~cm}, 11$. Bolivina tongi var. filacostata 59-1; $523 \mathrm{~cm}, 12$. Buliminella cf. curta $50-4 ; 100 \mathrm{~cm}$, 13. Suggrunda eckisi 50-4; $110 \mathrm{~cm}$, 14. Suggrunda porosa 47-2; $128 \mathrm{~cm}, 15$. Fursenkoina fusiformis $50-4 ; 230 \mathrm{~cm}$, 16. Fursenkoina glabra $50-4 ; 230 \mathrm{~cm}$, 17. Buliminella elegantissima 416; $180 \mathrm{~cm}, 18$. Bulimina mexicana 52-2; $520 \mathrm{~cm}$, Bulimina pagoda 52-2; $520 \mathrm{~cm}$. 
ture of the costae are the most similar to the Bolivina interjuncta Cushman var. bicostata Cushman. The costae are not easily recognised because of the small size but they are unquestionably visible at SEM images. [Figures 12.5-6, 8.5].

Bolivina minima Phleger and Parker, 1951.

Bolivina ordinaria Phleger and Parker, 1952. [Figures $12.2,8.9]$.

Bolivina pacifica $=$ Bolivina acerosa Cushman var. pacifica Cushman and McCulloch, 1942. [Figures 7.10, 12.4].

Bolivina plicata d'Orbigny, 1839. [Figures 10.3-4, 11.2-3].

Bolivina quadrata Cushman and McCulloch, 1942.

Bolivina semicostata Cushman, 1911.

Bolivina seminuda Cushman, 1911. [Figures 12.4, 8.1].

Bolivina seminuda Cushman var. humilis Cushman and McCulloch, 1942.

Note: Bolivina seminuda Cushman var. humilis showed huge variations in the samples similar to those provided as type figures. [Figures 12.9, 8.3].

Bolivina cf. seminuda Cushman var. humilis

Note: This species is similar to the type specimen figured in Cushman and McCulloch (1942, pl. 26, fig. 1a) and it has projections and acute periphery in early chambers similar to Bolivina minima but it is not as flat and compressed as B. minima. Considering overall appearance, inflated later chambers, structure of the aperture, and the appearance of the pores, it is considered as a variation of $B$. seminuda var. humilis and could be merged into this group. [Figures 12.3, 8.2].

Bolivina serrata $=$ Bolivina subadvena Cushman var. serrata Natland, 1938.

Bolivina spissa = Bolivina subadvaena Cushman var. spissa Cushman 1926a. [Figures 10.7, 11.4].

Bolivina subadvena Cushman, 1926a. [Figure 10.2].

Bolivina subaenariensis Cushman, 1922.

Bolivina tongi Cushman var. filacostata Cushman and McCulloch, 1942. [Figure 12.11].

Bolivina tortuosa Brady, 1881 p. 57, illustrated by Brady, 1884.

Bolivina aff. tortuosa

Note: The almost $90^{\circ}$ twisted feature and coarse pores of this species are similar to Bolivina tortuosa though the specimens found in the sediment samples are really small in size, not exceeding $150 \mu \mathrm{m}$ in length and they are compressed. [Figures 12.8, 8.7].

Bolivinita minuta = Bolivina minuta Natland, 1938 [Figures $12.7,8.6]$.

cf. Buccella peruviana = Rotalina peruviana d'Orbigny, 1839.

Note: Except the appearance of the aperture, other features are similar to those described in the type reference. Buccella plana of McCulloch, 1977 exhibits similar features but the appearance of the aperture is different in the specimens of our samples. [Figures 7. 9-10, 8.15-17].

Bulimina denudata = Bulimina pagoda Cushman var. denudata Cushman and Parker, 1938.
Bulimina exilis = Bulimina elegans d'Orbigny var. exilis Brady, 1884.

Note: Most of the taxonomical studies from Eastern Pacific denominate this species as Buliminella tenuata Cushman or Bulimina exilis var. tenuata Cushman. The species name Bulimina exilis Brady 1884 is considered to have priority though. [Figures 10.14$15,11.12-13]$.

Bulimina marginata d'Orbigny 1826.

Bulimina mexicana = Bulimina inflata Seguenza var. mexicana Cushman, 1922. [Figure 12.18].

Bulimina pagoda Cushman, 1927. [Figures 12.19, 8.10].

Bulimina rostrata Brady, 1884.

Bulimina striata d'Orbigny, 1826.

Buliminella curta Cushman, 1925. [Figures 12.12, 11.11].

Buliminella curta Cushman var. basispinata Stewart and Stewart, 1930. [Figure 10.16].

Buliminella elegantissima $=$ Bulimina elegantissima d'Orbigny, 1839 [Figure 12.17].

Buliminella tenuata = Buliminella subfusiformis var. tenuata Cushman, 1927

Note: Not Bulimina tenuata Cushman. In our samples, this species is small in size and has an aperture with tooth. [Figure 10.11].

Cancris auriculus $=$ Nautilus auricula Fichtel and Moll, 1798.

Cancris carmenensis Natland, 1950.

Cancris inflatus = Valvulina inflata d'Orbigny, 1839.

Cassidulina auka Boltovskoy and Theyer, 1970 [Figures 7.11, 11.19].

Cassidulina carinata = Cassidulina laevigata d'Orbigny var. carinata Silvestri, 1896 [Figures 7.16, 13.15].

Cassidulina corbyi Cushman and Hughes, 1925.

Cassidulina crassa d'Orbigny, 1839 [Figures 10.18, 11.18]

Cassidulina delicata Cushman, 1927

Note: We followed the suggestion of Uchio (1960) and included Cassidulina cushmani Stewart and Stewart, 1930 into the range of variability of this species. [Figures 7.17, 11.17].

Cassidulina depressa Asano and Nakamura, 1937.

Cassidulina laevigata d'Orbigny, 1826.

Cassidulina minuta Cushman, 1933. [Figure 7.15].

Cassidulina pulchella d'Orbigny, 1839.

Chilostomella ovoidea Reuss, 1850.

Cibicides aknerianus = Rotalina akneriana d'Orbigny, 1846.

Cibicides elmaensis Rau, 1948.

Cibicides floridanus = Truncatulina floridana Cushman, 1918.

Cibicides mckannai Galloway and Wissler, 1927 [Figure 13.2].

Cibicides spiralis Natland, 1938.

Cibicidoides dispars = Truncatulina dispars d'Orbigny, 1839.

Cibicidoides mundulus = Truncatulina mundula Brady, Parker, and Jones, 1888.

Cibicidoides wuellerstorfi = Anomalina wuellerstorfi Schwager, 1866 [Figure 13.1]. 


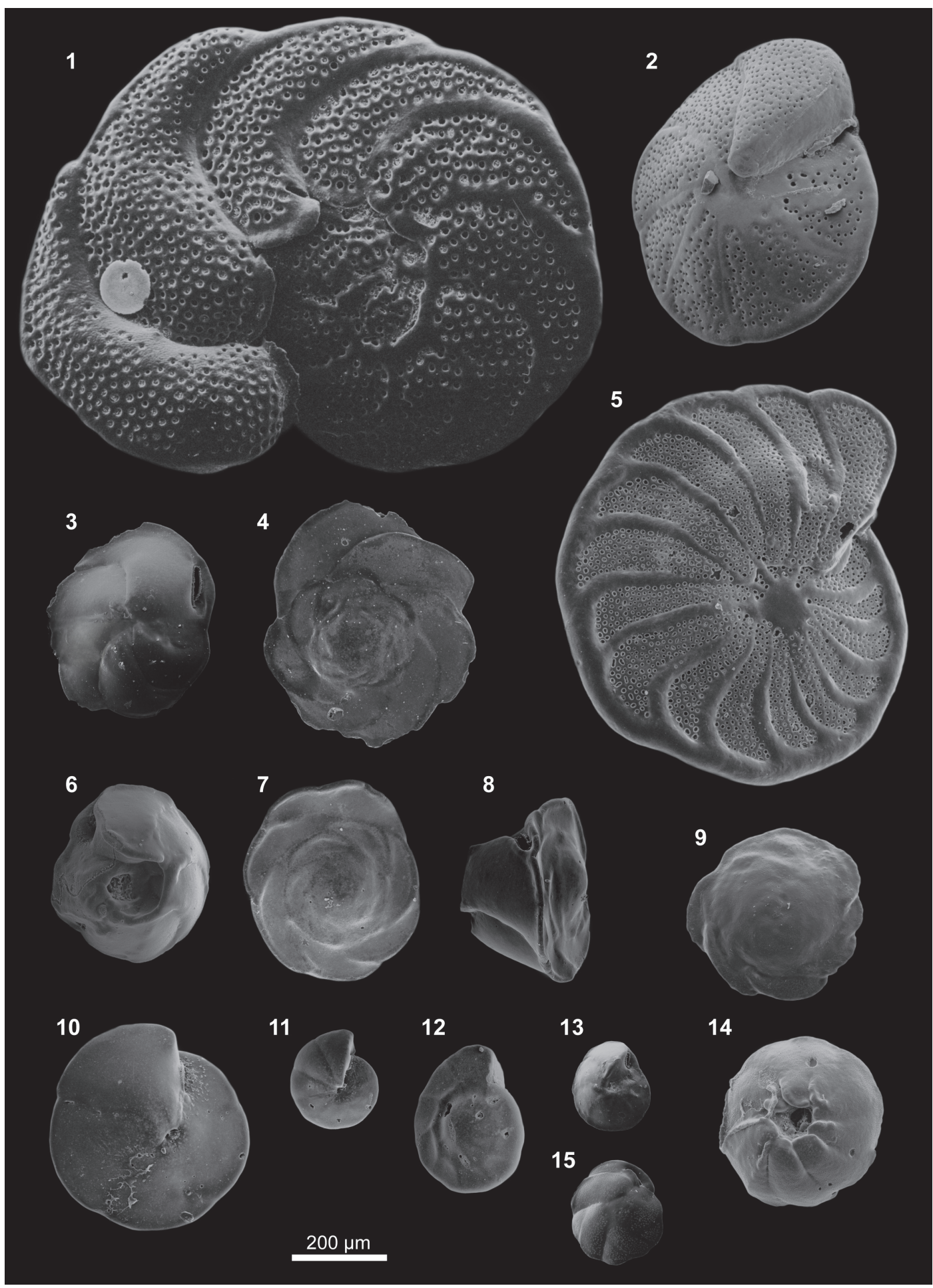

FIGURE 13. SEM images; scale bar equals $200 \mu \mathrm{m}$. 1. Cibicidoides wuellerstorfi spiral view $52-2 ; 500 \mathrm{~cm}, 2$. Cibicides mckannai umbilical view 52-2; $230 \mathrm{~cm}$, 3. Epistominella smithi umbilical view 50-4; $210 \mathrm{~cm}$, 4 . Epistominella smithi spiral view $50-4 ; 210 \mathrm{~cm}, 5$. Planulina limbata umbilical view $416 ; 100 \mathrm{~cm}, 6$. Epistominella pacifica umbilical view 416; $200 \mathrm{~cm}, 7$. Epistominella pacifica spiral view 416; $200 \mathrm{~cm}$, 8. Epistominella pacifica peripheral view 416 ; $200 \mathrm{~cm}, 9$. Gyroidina rothwelli spiral view 416; $100 \mathrm{~cm}, 10$. Oridorsalis umbonatus umbilical view $52-2 ; 230 \mathrm{~cm}, 11$. Gyroidina subtenera umbilical view 52-2; $230 \mathrm{~cm}, 12$. Gyroidina subtenera spiral view 52-2; $270 \mathrm{~cm}, 13$. Epistominella pacifica umbilical view 47-2; $128 \mathrm{~cm}, 14$. Gyroidina rothwelli umbilical view 416; $100 \mathrm{~cm}, 15$. Cassidulina carinata $50-4 ; 210 \mathrm{~cm}$. 
Dentalina advena = Nodosaria advena Cushman, 1923. Discorbis micens Cushman, 1933.

Discorbis peruvianus = Rosalina peruviana d'Orbigny, 1839.

Dorothia goesii = Textularia goesii Cushman, 1911.

Ehrenbergina pupa = Cassidulina pupa d'Orbigny, 1839 .

Epistominella afueraensis McCulloch, 1977.

Note: The acute periphery and keeled appearance of chambers discriminates this species from Epistominella obesa. [Figures 9.8-9, 8.21-23].

Epistominella exigua = Pulvinulina exigua Brady, 1884 . [Figures 7.2-3, 8.18-19].

Epistominella obesa Bandy and Arnal, 1957.

Note: Bandy and Arnal (1957) described this species as similar to Pulvinulinella bradyana Cushman, 1927 but with more inflated chambers. In the sediment samples, it is difficult to distinguish these two species. Based on the structure of the aperture they are treated here together as Epistominella obesa. [Figures 7.6-8].

Epistominella pacifica $=$ Pulvinulinella pacifica Cushman, 1927.

Note: In our samples this species exhibited variations such as size, keel type, or transparency. Specimens of Epistominella sp. figured by Resig (1981) and Coulbourn (1980) are similar to those observed in the studied sediment samples and, therefore are considered to be in the range of intraspecific variability. [Figures 9.2-3, 7.1, 13.6-8, 13.13].

Epistominella smithi $=$ Pulvinulinella smithi Stewart and Stewart, 1930. [Figures 9.5, 13.3-4].

Eponides pusillus Parr, 1950.

Fissurina alatifundata McCulloch, 1981.

Fissurina alveolata = Lagena alveolata Brady, 1884 .

Fissurina annectens = Lagena annectens Burrows and Holland, 1895.

Note: Type reference given by Jones, 1895.

Fissurina exculpta = Lagena exculpta Brady, 1881, p. 61, illustrated by Brady, 1884.

Fissurina kerguelenensis Parr, 1950.

Fissurina laevigata Reuss, 1850.

Fissurina marginata $=$ Vermiculum marginatum Montagu, 1803, illustrated by Walker and Boys, 1784.

Fissurina orbignyana Seguenza, 1862.

Fissurina semimarginata $=$ Lagena marginata (Montagu) var. semimarginata Reuss, 1870.

Fursenkoina fusiformis = Bulimina pupoides d'Orbigny var. fusiformis Williamson, 1858 [Figures 12.15, 8.11].

Fursenkoina glabra = Bulimina patagonica d'Orbigny var. glabra Cushman and Wickenden, 1929 [Figures 12.16, 8.13].

Globobulimina affinis = Bulimina affinis d'Orbigny, 1839 .

Globobulimina glabra Cushman and Parker, 1947.

Globobulimina hoeglundi Uchio, 1960.

Globobulimina ovula = Bulimina ovula d'Orbigny, 1839

Globobulimina pacifica Cushman, 1927 [Figures 10.12, 11.16].
Globocassidulina paratortuosa $=$ Cassidulina paratortuosa Kuwano, 1954.

Globocassidulina subglobosa = Cassidulina subglobosa Brady, 1881.

Gyroidina altiformis = Gyroidina soldanii d'Orbigny var. altiformis Stewart and Stewart, 1930

Gyroidina gemma Bandy, 1953.

Gyroidina lamarckiana = Rotalina lamarckiana d'Orbigny, 1839.

Gyroidina neosoldanii Brotzen, 1936.

Gyroidina nitidula = Rotalia nitidula Schwager, 1866.

Gyroidina polia = Eponides polius Phleger and Parker, 1951.

Gyroidina quinqueloba Uchio, 1960.

Gyroidina rothwelli Natland, 1950. [Figures 9.10-11, 13.9, 13.14].

Gyroidina soldanii d'Orbigny, 1826.

Gyroidina subtenera = Rotalia subtenera Galloway and Wissler, 1927 [Figures 7.13-14, 13.11-12].

Hanzawaia bertheloti = Rosalina bertheloti d'Orbigny, 1839.

Hanzawaia mexicana Lankford, 1973.

Hoeglundina elegans $=$ Rotalia (Turbinuline) elegans d'Orbigny, 1826 [Figure 11.15].

Lagena amphora Reuss, 1863.

Lagena distoma Parker and Jones, 1864.

Lagena elongata = Miliola elongate Ehrenberg, 1845.

Lagena gracillima = Amphorina gracillima Seguenza, 1862.

Lagena hispidula Cushman, 1923.

Lagena laevis = Vermiculum laeve Montagu, 1803.

Lagena lateralis Cushman, 1913a.

Lagena meridionalis = Lagena gracilis Williamson var. meridionalis Wiesner, 1931.

Lagena semistriata = Lagena striata (Montagu) var. semistriata Williamson, 1848.

Lagena squamosa = Vermiculum squamosum Montagu, 1803.

Lagena striata = Oolina striata d'Orbigny, 1839.

Lagena substriata Williamson, 1848.

Lagena sulcata $=$ Serpula (Lagena) sulcata Walker and Jacob, 1798.

Lagena sulcata (Walker and Jacob) var. pecularis Cushman and McCulloch, 1950.

Lagena sulcata (Walker and Jacob) var. striatopunctata Parker and Jones, 1865.

Lagena williamsoni Harvey and Bailey, 1854.

Lagenosolenia inflatiperforata McCulloch, 1977.

Laticarinina pauperata $=$ Pulvinulina repanda Fichtel and Moll var. menardii d'Orbigny subvar. pauperata Parker and Jones, 1865.

Lenticulina convergens = Cristellaria convergens Bornemann, 1855

Lenticulina limbosa $=$ Cristellaria (Robulina) limbosa Reuss, 1863.

Martinottiella communis $=$ Clavulina communis d'Orbigny, 1846.

Martinottiella nodulosa = Clavulina communis d'Orbigny var. nodulosa Cushman, 1922. 
Melonis affinis = Nonionina affinis Reuss, 1851.

Melonis barleeanum = Nonionina barleeana Williamson, 1858.

Melonis pompilioides $=$ Nautilus pompilioides Fichtel and Moll, 1798.

Nonion commune = Nonionina communis d'Orbigny, 1846.

Nonion pizarrensis Berry var. basispinata Cushman and Moyer, 1930.

Nonionella cf. auricula Heron-Allen and Earland, 1930.

Nonionella auris = Valvulina auris d'Orbigny, 1839 .

Nonionella iridea Heron-Allen and Earland, 1932.

Nonionella labradorica = Nonionina labradorica Dawson, 1860.

Nonionella miocenica Cushman, 1926b.

Nonionella stella = Nonionella miocenica Cushman var. stella Cushman and Moyer, 1930.

Nonionella turgida = Rotalina turgida Williamson, 1858.

Nonionoides grateloupii = Nonionina grateloupii d'Orbigny, 1826.

Oolina apiculata Reuss, 1851.

Oolina globosa = Vermiculum globosum Montagu, 1803

Oolina truncata = Lagena truncata Brady, 1884 .

Oridorsalis umbonatus = Rotalina umbonata Reuss, 1851. [Figure 13.10].

Planulina limbata Natland, 1938. [Figures 9.1, 13.5].

Planulina ornata = Truncatulina ornata d'Orbigny, 1839.

Praeglobobulimina ovata = Bulimina ovata d'Orbigny, 1846.

Praeglobobulimina spinescens = Bulimina pyrula d'Orbigny var. spinescens Brady, 1884 [Figures 10.6, 11.6].

Pseudoparella subperuviana $=$ Pulvinulinella subperuviana Cushman, 1926b.

Pseudoparella sp.

Note: Small juvenile specimens with large umbilicus. They potentially belong to Pseudoparella group but as indicated in the note for Epistominella obesa, the differences reported between these two species are difficult to discriminate in our samples.

Pullenia bulloides = Nonionina bulloides d'Orbigny, 1846.

Pullenia elegans Cushman and Todd, 1943.

Pullenia quinqueloba = Nonionina quinqueloba Reuss, 1851.

Pullenia subcarinata = Nonionina subcarinata d'Orbigny, 1839.

Pyrgo depressa = Biloculina depressa d'Orbigny, 1826.

Pyrgo lucernula = Biloculina lucernula Schwager, 1866.

Pyrgo murrhyna = Biloculina murrhina Schwager, 1866.

Pyrgo serrata = Biloculina serrata Bailey, 1861.

Quinqueloculina seminulum = Serpula seminulum Linné, 1758.

Quinqueloculina triangularis d'Orbigny, 1846.

Stainforthia complanata = Virgulina schreibersiana Czjzek var. complanata Egger, 1893. [Figures 10.9, 11.7].

Suggrunda eckisi Natland, 1950. [Figure 12.13].

Suggrunda porosa Hoffmeister and Berry, 1937. [Figure 12.14].
Uvigerina cf. acuelata d'Orbigny, 1846.

Uvigerina auberiana d'Orbigny, 1839. [Figure 10.17, 11.8].

Uvigerina bifurcata d'Orbigny, 1839.

Uvigerina canariensis d'Orbigny, 1839.

Uvigerina curticosta = Uvigerina pigmea d'Orbigny var. curticosta Cushman, 1927.

Uvigerina excellens Todd, 1948.

Uvigerina hispida Schwager, 1866.

Uvigerina peregrina Cushman, 1923. [Figures 10.13, 11.5].

Uvigerina semiornata d'Orbigny, 1846. [Figure 11.9].

Uvigerina senticosa Cushman, 1927

Uvigerina striata d'Orbigny, 1839. [Figures 9.6, 11.14].

Valvulineria araucana = Rosalina araucana d'Orbigny, 1839.

Valvulineria bradyana Fornasini, 1900.

Valvulineria californica Cushman, 1926b.

Valvulineria glabra = Valvulineria vilardeboana (d'Orbigny) var. glabra Cushman, 1927.

Valvulineria cf. involuta Cushman and Dusenburry, 1934. Valvulineria minuta Parker, 1954.

Valvulineria cf. olssoni Redmond, 1953.

Valvulineria rugosa = Rosalina rugosa d'Orbigny, 1839.

Virgulina apertura Uchio, 1960.

Virgulina bradyi Cushman, 1922.

Virgulina bramlettei Galloway and Morrey, 1929.

Virgulina cornuta Cushman, 1913b.

Virgulina pauciloculata Brady, 1884.

Virgulina schreibersiana Czjzek, 1848.

Virgulina spinosa = Virgulina schreibersiana Czjzek var. spinose Heron-Allen and Earland, 1932. [Figure 12.12].

\section{ACKNOWLEDGEMENTS}

We thank the crew and captain of $R / V$ Meteor during the cruises M77 legs 1 and 2, N. Glock, A.E. Rathburn, M. Pérez, and J. Cardich for their support during this study, W. Kuhnt and his group for helping with the optical microscopic imaging and $\mathrm{S}$. Meyer and his team for providing the SEM facilities. We also would like to thank the two reviewers and the editor M. Hyžný for improving this paper significantly. This work was funded by Deutsche Forschungsgemeinschaft (DFG) through SFB 754 "Climate-Biogeochemistry Interactions in the Tropical Ocean."

\section{REFERENCES}

Alve, E. and Bernhard, J.M. 1995. Vertical migratory response of benthic foraminifera to controlled oxygen concentrations in an experimental mesocosm. Marine Ecology Progress Series, 116:137-151.

Alve, E., Korsun, S., Schönfeld, J., Dijkstra, N., Golikova, E., Hess, S., Husum, K., and Panieri, G. 2016. Foram-AMBI: A sensitivity index based on benthic 
foraminiferal faunas from North-East Atlantic and Arctic fjords, continental shelves and slopes. Marine Micropalaeontology, 122:1-12.

Asano, K. and Nakamura, M. 1937. On the Japanese species of Cassidulina. Japanese Journal of Geology and Geography, 14(2-3):143-153.

Asteman, I.P. and Nordberg, K. 2013. Foraminiferal fauna from a deep basin in Gullmar Fjord: The influence of seasonal hypoxia and North Atlantic Oscillation. Journal of Sea Research, 79:40-49.

Bailey, L.W. 1861. Notes on new species of microscopical organisms, chiefly from the Para River, South America, Boston Journal of Natural History, 7:3.

Bandy, O.L. 1953. Ecology and palaeoecology of some California foraminifera part I. The frequency distribution of recent foraminifera off California. Journal of Palaeontology, 27:161-185.

Bandy, O.L. and Arnal, R.E. 1957. Distribution of recent foraminifera off west coast of Central America. Bulletin AAPG, 41(9):2037-2053.

Bandy, O.L. and Rodolfo, K.S. 1964. Distribution of foraminifera and sediments, Peru-Chile Trench Area. Deep-Sea Research, 11:817-837.

Barker, R.W. 1960. Taxonomic notes on the species figured by H.B.Brady in his report on the foraminifera dredged by H.M.S. Challenger during the years 1873-1876. Society of Economic Palaeontologists and Mineralogists, Tulsa, Oklahoma, USA.

Bernhard, J.M. and Sen Gupta, B.K. 1999. Foraminifera of oxygen-depleted environments, pp. 201-216. In Sen Gupta, B.K. (ed.) Modern Foraminifera. Springer.

Boltovskoy, E. and Theyer, F. 1970. Foraminíferos recientes de Chile Central. Revista del Museo Argentino de Ciencias Naturales "Bernardino Rivadavia", 2(9):280-397.

Bornemann, J.G. 1855. Die mikroskopische Fauna des Septarienthones von Hermsdorf bei Berlin. Zeitschrigt der Deutschen Geologischen Gesellschaft, 7(2):307-371.

Brady, H.B. 1881. Notes on some of the reticularian Rhizopoda of the Challenger Expedition, Part 3. Quarterly Journal of Microscopical Science, 21:31-71.

Brady, H.B. 1884. Report on the foraminifera dredged by H.M.S. "Challenger" during the years 1873-1876, In Report on the scientific results of the voyage H.M.S. Challenger during the years 1873-1876, Zoology, 9:814.

Brady, H.B., Parker, W.K., and Jones, T.R. 1888. On some foraminifera from the Abrohlos Bank, Transactions of the Zoological Society of London, London, $12,7,1$.

Broecker, W.S., Denton, G.H., Edwards, R.L., Cheng, H., Alley, R.B., and Putnam, A.E. 2010. Putting the Younger Dryas cold event into context. Quaternary Science Reviews, 29(9):1078-1081.

Brotzen, F. 1936. Foraminiferen aus dem schwedischen, untersten Senon von Eriksdal in Schonen. Arsbok Sveriges Geologiska Undersögning, C(396).
Burrows, H.W. and Holland, R. 1895. A monograph of the foraminifera of the crag, Pt. 2, pp. 73-210. In Jones, T.R., Parker, W.K., and Brady, H.B. (eds.), A Monograph of the Foraminifera of the Crag.

Cardich, J., Gutiérrez, D., Romero, D., Pérez, A., Quipúzcoa, L., Marquina, R., Yupanqui, W., Solís, J., Carhuapoma, W., Sifeddine, A., and Rathburn, A. 2015. Calcareous benthic foraminifera from the upper central Peruvian margin: control of the assemblage by pore water redox and sedimentary organic matter. Marine Ecology Progress Series, 535:63-87.

Cardich, J., Morales, M., Quipúzcoa, L., Sifeddine, A., and Gutiérrez, D. 2012. Benthic foraminiferal communities and microhabitat selection on the continental shelf off Central Peru, pp. 323-340. In Altenbach, A.V., Bernhard, J.M., Seckbach, J. (eds.), Anoxia: Evidence for Eukaryote Survival and Palaeontological Strategies, Springer.

Caulle, C., Koho, K.A., Mojtahid, M., Reichart, G.J., and Jorissen, F.J. 2014. Live (Rose Bengal stained) foraminiferal faunas from the northern Arabian Sea: faunal succession within and below the OMZ. Biogeosciences, 11:1155-1175.

Coulbourn, W.T. 1980. Relationship between the distribution of foraminifera and geologic structures of the Arica bight, South America. Journal of Palaeontology, 54:696-718.

Cushman, J.A. 1911. A monograph of the foraminifera of the North Pacific Ocean, Pt. 2, Textulariidae. U.S. Natural History Museum Bulletin, 71.

Cushman, J.A., 1913a. A monograph of the foraminifera of the North Pacific Ocean, Pt. 3, Lagenidae. U.S. Natural History Museum Bulletin, 71.

Cushman, J.A. 1913b. New Textulariidae and other arenaceous Foraminifera from the Philippine Islands and contiguous waters. Proceedings of U.S. Natural Museum, 44:633- 638.

Cushman, J.A. 1918. Some Miocene foraminifera of the Coastal Plain of the United States. U.S. Geological Survey Bulletin, Washington, D.C., 676.

Cushman, J.A. 1922. The foraminifera of the Atlantic Ocean, Pt. 3, Textulariidae. U.S. Natural History Museum Bulletin, 104.

Cushman, J.A. 1923. The foraminifera of the Atlantic Ocean, Pt. 4. Lagenidae. U.S. Natural History Museum Bulletin, 104.

Cushman, J.A. 1925. Some Textulariidae from the Miocene of California. Contributions from the Cushman Laboratory for Foraminiferal Research, Sharon, Mass., USA. 1(2):29-35.

Cushman, J.A. 1926a. Some Pliocene Bolivinas from California. Contributions from the Cushman Laboratory for Foraminiferal Research, Sharon, Mass., USA. 2(2):40-47.

Cushman, J.A. 1926b. Foraminifera of the typical Monterey of California. Contributions from the Cushman Laboratory for Foraminiferal Research, 2(3):53-69.

Cushman, J.A. 1927. Recent foraminifera from off the West Coast of America, University of California, 
Scripps Institute Oceanography Bulletin, Technical Series, 1(10):119-188.

Cushman, J.A. 1933. Some new Recent foraminifera from the Tropical Pacific. Contributions from the Cushman Laboratory for Foraminiferal Research, 9(4):77-95.

Cushman, J.A. 1937. A monograph of the subfamily Virgulininae of the foraminiferal family Buliminidae. Contributions from the Cushman Laboratory for Foraminiferal Research, Special Publications No. 9.

Cushman, J.A. and Dusenburry, jr., A.N. 1934. Eocene foraminifera of the Poway Conglomerate of California. Contributions from the Cushman Laboratory for Foraminiferal Research,10(3):51-65.

Cushman, J.A. and Hughes, D.D. 1925. Some later Tertiary Cassidulinas of California. Contributions from the Cushman Laboratory for Foraminiferal Research, 99:11-17.

Cushman, J.A. and McCulloch, I. 1942. Some Virgulininae in the collections of the Allan Hancock Foundation. Allan Hancock Pacific Expeditions, 6(4):179230.

Cushman, J.A. and McCulloch, I. 1950. Some Lagenidae in the Collections of the Allan Hancock Foundation. Allan Hancock Pacific Expeditions, 6(6):295-364.

Cushman, J.A. and Moyer, D.A. 1930. Some Recent foraminifera from off San Pedro, California. Contributions from the Cushman Laboratory for Foraminiferal Research, 6(3):49-62.

Cushman, J.A. and Parker, F.L. 1938. Notes on some Pliocene and Pleistocene species of Bulimina and Buliminella. Contributions from the Cushman Laboratory for Foraminiferal Research, 14(3):53-62.

Cushman, J.A. and Parker, F.L. 1947. Bulimina and related foraminiferal genera. Professional Papers U.S. Geological Survey, 210-D:55-176.

Cushman, J.A. and Todd, R., 1943. The genus Pullenia and its species Contributions from the Cushman Laboratory for Foraminiferal Research, 19(1).

Cushman, J.A. and Wickenden, R.T.D. 1929. Recent foraminifera from off Juan Fernandez Islands. U.S. Natural Museum Proceedings, Washington, D.C., USA, 2780(75):9.

Czeschel, R., Stramma, L., and Johnson, G.C. 2012. Oxygen decreases and variability in the eastern equatorial Pacific. Journal of Geophysical Research: Oceans, 117:(C11).

Czjzek, J., 1848. Beitrag zur Kenntnis der fossilen Foraminiferen des Wiener Beckens. Heidinger's Naturwissenschaftlich Abhandlung, Wien, Österreich, 2(1):137-150.

Dale, A.W., Sommer, S., Lomnitz, U., Montes, I., Treude, T., Liebetrau, V., Gier, J., Hensen, C., Dengler, M., Stolpovsky, K., and Bryant, L.D. 2015. Organic carbon production, mineralization and preservation on the Peruvian margin. Biogeosciences (BG), 12:15371559.

Dawson, J.W. 1860. Notice of Tertiary fossils from Labrador, Maine, etc., and remarks on the climate of Can- ada in the newer Pliocene or Pleistocene record. Canadian National Geology, Montreal, vol. 5.

de Nooijer, L. 2007. Shallow water benthic foraminifera as proxy for natural versus human-induced environmental change. Doctoral thesis, Utrecht University, Utrecht, The Netherlands.

den Dulk, M., Reichart, G.-J., Heyst, S.V., Zachariasse, W.J., and Van der Zwaan, G.J. 2000. Benthic foraminifera as proxies of organic matter flux and bottom water oxygenation? A case history from the northern Arabian Sea. Palaeogeography, Palaeoclimatology, Palaeoecology, 161:337-359.

d'Orbigny, A.D. 1826. Tableau méthodique de la classe des Céphalopodes. Annales des Sciences Naturales Paris, 1(7):245-315.

d'Orbigny, A.D. 1839. Voyage dans l'Amérique méridionale. Foraminifères, 5(5), Levrault, Strasbourg, France.

d'Orbigny, A.D. 1846. Foreminifères fossiles du Bassin Tertiaire de Vienne (Autriche), Gide et Compe, Paris.

Douglas, R.G. and Heitman, H.L. 1979. Slope and basin benthic foraminifera of the California Borderland. Society of Economic Palaeontologists and Mineralogists, 27:231-246.

Earland, A. 1936. Foraminifera; part IV - additional records from the Weddell Sea sector from material obtained by the S.Y. 'Scotia'. Discovery Reports. Cambridge, vol. 13.

Egger, J.G. 1893. Foraminiferen aus Meeresgrundproben, gelothet von 1874 bis 1876 S.M. Sch. Gazelle. Abhandlungen der Bayrischen Akademie der Wissenschaften,18(2):266-311.

Ehrenberg, C.G. 1845. Das kleinste organische Leben an mehreren bisher nicht untersuchen Erdpunkten; Mikroskopische Lebensformen von Portugal und Spanien, Süd-Afrika, Hinter-Indien, Japan und Kurdistan. K. Preuss. Akademie der Wissenschaften, Berlin.

Elderfield, H., Bertram, C.J., and Erez, J. 1996. A biomineralization model for the incorporation of trace elements into foraminiferal calcium carbonate. Earth and Planetary Science Letters, 142(3-4):409-423.

Ellis, B.F. and Messina, A. (1940 and onwards). Catalogue of Foraminifera. www.micropress.org

Erdem, Z. 2015. Taxonomy workshop on Recent benthic foraminifera. Newsletter of Micropalaeontology, 92:44.

Erdem, Z., Schönfeld, J., Glock, N., Dengler, M., Mosch, T., Sommer, S., Elger, J., and Eisenhauer, A. 2016. Peruvian sediments as recorders of an evolving hiatus for the last 22 thousand years. Quaternary Science Reviews, 137:1-14.

Figueroa, S., Marchant, M., Giglio, S., and Ramirez, M. 2005. Foraminiferos bentonicos rotalinidos del centro sur de Chile (36 $\left.6^{\circ}-44^{\circ} \mathrm{S}\right)$. Gayana 69:329-363.

Fisher, R.A., Corbet, A.S., and Williams, C. B. 1943. The relation between the number of species and the number of individuals in a random sample of an animal population. The Journal of Animal Ecology, 42-58. 
Fornasini, C. 1900. Intorno ad alcuni esemplari di foraminiferi Adriatici. R. Accademia Scienza Istituto di Bologna, 5(8).

Fuenzalida, R., Schneider, W., Garces-Vargas, J., Bravo, L., and Lange, C. 2009. Vertical and horizontal extension of the oxygen minimum zone in the eastern South Pacific Ocean. Deep-Sea Research Pt II 56:1027-1038.

Galloway, J.J. and Morrey, M. 1929. A Lower Tertiary foraminiferal fauna from Manta, Ecuador. Bulletin of American Palaeontology, 15.

Galloway, J.J. and Wissler, S.G. 1927. Pleistocene foraminifera from the Lomita Quarry, Palos Verdes Hills, California. Journal of Palaeontology, 1:35-87.

Gooday, A.J. 1993. Deep-sea benthic foraminiferal species which exploit phytodetritus - characteristic features and controls on distribution. Marine Micropalaeontology, 22:187-205.

Gooday, A.J. 2003. Benthic foraminifera (protista) as tools in deep-water palaeoceanography: Environmental influences on faunal characteristics, pp. 1-90. In Southward, A.J., Tyler, P.A., Young, C.M., Fuiman, L.A. (eds.), Advances in Marine Biology, Academic Press.

Gooday, A.J. and Rathburn, A.E. 1999. Temporal variability in living deep-sea benthic foraminifera: a review. Earth-Science Reviews, 46:187-212.

Gooday, A.J., Bernhard, J.M., Levin, L.A., and Suhr, S.B. 2000. Foraminifera in the Arabian Sea oxygen minimum zone and other oxygen-deficient settings: taxonomic composition, diversity, and relation to metazoan faunas. Deep Sea Research Part II, 47:2554.

Hammer, Ø., Harper, D.A.T., and Ryan, P.D. 2001. PAST: Palaeontological statistics software package for education and data analysis. Palaeontologia Electronica 4(1). palaeo-electronica.org/2001_1/past/issue1_01.htm.

Harvey, W.H. and Bailey, J.W. 1854. New species of Diatomaceae, collected by the U.S. Exploring Expedition, under the command of Capt. Wikes. U.S., National Academy of Natural Science. Philadelphia, Proceedings, vol. 6.

Heinze, P.-M. and Wefer, G. 1992. The history of coastal upwelling off Peru $\left(11^{\circ} \mathrm{S}\right.$, ODP Leg 112 , Site 680B) over the past 650,000 years. Geological Society Special Publications, 64(1): 451-462.

Helly, J.J. and Levin, L.A. 2004. Global distribution of naturally occurring marine hypoxia on continental margins. Deep Sea Research Part I: Oceanographic Research Papers, 51:1159-1168.

Hendy, I.L. and Pedersen, T.F. 2006. Oxygen minimum zone expansion in the eastern tropical North Pacific during deglaciation. Geophysical Research Letters, 33.

Heron-Allen, E. and Earland, A. 1930. The foraminifera of the Plymouth district, pt. 1. Journal of Microscopy, $50(1): 46-84$.
Heron-Allen, E. and Earland, A. 1932. Foraminifera, part I - The ice-free area of the Falkland Islands and adjacent seas. Discovery Reports, 4:291-460.

Hoffmeister, W.S. and Berry, C.T. 1937. A new genus of foraminifera from the Miocene of Venezuela and Trinidad. Journal of Palaeontology, 11(1):29-30.

Ingle, J.C., Keller, G., and Kolpack, R.L. 1980. Benthic foraminiferal biofacies, sediments and water masses of the southern Peru-Chile Trench area, southeastern Pacific Ocean. Micropalaeontology, 26:113-150.

Jennings, A.E., Weiner, N.J., Helgadottir, G., and Andrews, J.T. 2004. Modern foraminiferal faunas of the southwestern to northern Iceland shelf: oceanographic and environmental controls. Journal of Foraminiferal Research, 34(3):180-207.

Jones, T.R. 1895. A monograph of the foraminifera of the crag, pt. 2. Palaeontology Society, London.

Karstensen, J., Stramma, L., and Visbeck, M. 2008. Oxygen minimum zones in the eastern tropical Atlantic and Pacific oceans. Progress in Oceanography, 77(4):331-350.

Khusid, T.A. 1974. Distribution of Benthic Foraminifers Off West Coast of South-America. OceanologyUSSR, 14:900-904.

Krissek, L.A., Scheidegger, K.F., and Kulm, L.D. 1980. Surface sediments of the Peru-Chile continental-margin and the Nazca Plate. Geological Society of America Bulletin, 91:321-331.

Kuwano, Y. 1954. Notes on the genus Cassidulina and allied genera from Japan, 2; Description of new species of Cassidulina from the Pliocene of southern Kwanto region. Res. Inst. Nat. Res., Misc. Reports, 35.

Lankford, R.R. 1973. Foraminifera from the nearshore turbulent zone, western North America. Journal of Foraminiferal Research 3(3):101-132.

Lear, C.H., Elderfield, H., and Wilson, P.A. 2000. Cenozoic deep-sea temperatures and global ice volumes from $\mathrm{Mg} / \mathrm{Ca}$ in benthic foraminiferal calcite. Science, 287(5451):269-272

Levin, L., Gutierrez, D., Rathburn, A., Neira, C., Sellanes, J., Munoz, P., Gallardo, V., and Salamanca, M. 2002. Benthic processes on the Peru margin: a transect across the oxygen minimum zone during the 1997-98 El Nino. Progress in Oceanography, 53:127.

Linné, C. 1758. Systema naturae. 10th Edition, 1, Holmiae (Stockholm), L. Salvii.

Loeblich, A.R. and Tappan, H. 1988. Foraminiferal Genera and Their Classification. Van Nostrand Reinhold, New York.

Lutze, G.F., Pflaumann, U., and Weinholz, P. 1986. Jungquartäre Fluktuationen der benthischen Foraminiferenfaunen in Tiefsee-Sedimenten vor NWAfrika. Eine Reaktion auf Produktivitätsänderungen im Oberflächenwasser. Meteor Forschungs-Ergebnisse C, 40:163-180.

Mackensen, A., Hubberten, H.W., Bickert, T., Fischer, G., and Fütterer, D.K. 1993. The $\delta^{13} \mathrm{C}$ in benthic foramin- 
iferal tests of Fontbotia wuellerstorfi (Schwager) relative to the $\delta^{13} \mathrm{C}$ of dissolved inorganic carbon in southern ocean deep water: implications for glacial ocean circulation models. Palaeoceanography, 8(5):587-610.

Mallon, J. 2012. Benthic foraminifera of the Peruvian and Ecuadorian continental margin. Doctoral thesis, Christian-Albrechts-Universität zu Kiel, Kiel, Germany.

Mallon, J., Glock, N., and Schönfeld, J. 2012. The response of benthic foraminifera to low-oxygen conditions of the Peruvian oxygen minimum zone, pp. 305-321. In Altenbach, A.V., Bernhard, J.M., Seckbach, J. (eds.), Anoxia: Evidence for Eukaryote Survival and Palaeontological Strategies. Springer.

Manheim, F., Rowe, G.T., and Jipa, D. 1975. Marine phosphorite formation off Peru. Journal of Sedimentary Petrology, 45:243-251.

McCulloch, I. 1977. Qualitative observations on recent foraminiferal tests with emphasis on the Eastern Pacific. Pts. 1-3, Los Angeles, Univ. of Southern California.

Mendes, I., Dias, J.A., Schönfeld, J., and Ferreira, O. 2012. Distribution of living benthic foraminifera on the northern Gulf of Cadiz continental shelf. Journal of Foraminiferal Research, 42(1):18-38.

Moffitt, S.E., Hill, T.M., Ohkushi, K., Kennett, J.P., and Behl, R.J. 2014. Vertical oxygen minimum zone oscillations since $20 \mathrm{ka}$ in Santa Barbara Basin: A benthic foraminiferal community perspective. Palaeoceanography, 29(1):44-57.

Mollier-Vogel, E., Leduc, G., Böschen, T., Martinez, P., and Schneider, R.R. 2013. Rainfall response to orbital and millennial forcing in northern Peru over the last 18 ka. Quaternary Science Reviews, 76:2938.

Montagu, G. 1803. Testacea Britannica, or Natural History of British Shells, Marina, Land and Fresh Water, Including the Most Minute. Romsey, England, J.S. Hollis.

Morales, M., Field, D., Mayor Pastor, S., Gutierrez, D., Sifeddine, A., Ortlieb, L., Ferreira, V., Salvatteci, R., and Velazco, F. 2006. Variations in Foraminifera over the last 460 years from laminated sediments off the coast of Peru. Boletín de la Sociedad Geológica del Perú, 101:5-18.

Murray, J.W. 2006. Ecology and Applications of Benthic Foraminifera. Cambridge University Press.

Natland, M.L. 1938. New species of foraminifera from off the west coast of North America and from the later Tertiary of the Los Angeles Basin. University of California, Scripps Institute of Oceanography Bulletin, Technical Series, 4(5):137-163.

Natland, M.L. 1950. Report on the Pleistocene and Pliocene foraminifera, 1940 E.W. Scripps cruise to the Gulf of California. The Geological Society of America, New York, USA.

Parker, F.L. 1954. Distribution of the foraminifera in the northeastern Gulf of Mexico. Harvard Collection,
Museum Comp. Zoology Bulletin, Cambridge, Mass., $111,10$.

Parker, W.K. and Jones, T.R. 1864. In Brady, H.B. (ed.) Contributions to the knowledge of the foraminifera-on the Rhizopodal fauna of the Shetlands. Linn. Soc. London, Trans. London, 24(3):467.

Parker, W.K. and Jones, T.R. 1865. On some foraminifera from the North Atlantic and Arctic Oceans, including Davis Straits and Baffin's Bay. Phil. Trans. Royal Society, 155:325-441.

Parr, W.J. 1950. Foraminifera. Reports B.A.N.Z. Antarctic Research Expedition 1929-1931, ser. B (Zoology, Botany), 5(6):232-392.

Paulmier, A. and Ruiz-Pino, D. 2009. Oxygen minimum zones (OMZs) in the modern ocean. Progress in Oceanography, 80:113-128.

Pedersen, T.F. 1983. Increased productivity in the eastern equatorial Pacific during the last glacial maximum $(19,000$ to 14,000 yr B.P). Geology, 11:16.

Pfannkuche, O., Frank, M., Schneider, R., and Stramma, L. 2011. Climate-biogeochemistry interactions in the tropical ocean of the SE-American oxygen minimum zone Cruise No. 77, Leg 1-4 October 222008 - February 18, 2009 Talcahuano (Chile) - Callao (Peru) Colon (Panama), METEOR-Berichte 11-2. Institut für Meereskunde der Universität Hamburg.

Phleger, F.P. and Parker, F.L. 1951. Ecology of foraminifera, northwest Gulf of Mexico, Part 2: Foraminifer Species. Geological Society of America Memoir 46.

Phleger, F.P. and Parker, F.L. 1952. New names for northwestern Gulf of Mexico foraminifera. Cushman Foundation of Foraminiferal Research, Washington, D.C., 3(1).

Phleger, F.B. and Soutar, A. 1973. Production of benthic foraminifera in three east Pacific oxygen minima. Micropalaeontology, 19:110-115.

Rau, W.W. 1948. Foraminifera from the Porter shale (Lincoln formation) Grays Harber County, Washington. Journal of Palaentontology, 22.

Redmond, C.D. 1953. Miocene foraminifera from the Tubara beds of northern Colombia, Journal of Palaentontology, 27(5).

Reimer, P.J., Baillie, M.G.L., Bard, E., Bayliss, A., Beck, J.W., Blackwell, P.G., Ramsey, C.B., Buck, C.E., Burr, G.S., Edwards, R.L., Friedrich, M., Grootes, P.M., Guilderson, T.P., Hajdas, I., Heaton, T.J., Hogg, A.G., Hughen, K.A., Kaiser, K.F., Kromer, B., McCormac, F.G., Manning, S.W., Reimer, R.W., Richards, D.A., Southon, J.R., Talamo, S., Turney, C.S.M., van der Plicht, J., and Weyhenmeyer, C.E. 2009. IntCal09 and Marine09 radiocarbon age calibration curves, 050,000 years cal BP. Radiocarbon 51:1111-1150.

Reimer, J., Bard, E., Bayliss, A., Beck, J.W., Blackwell, P.G., Ramsey, C.B., Buck, C.E., Cheng, H., Edwards, R.L., Friedrich, M., Grootes, P.M., Guilderson, T.P., Haflidason, H., Hajdas, I., Hatte, C., Heaton, T.J., Hoffmann, D.L., Hogg, A.G., Hughen, K.A., Kaiser, K.F., Kromer, B., Manning, S.W., Niu, M., Reimer, R.W., Richards, D.A., Scott, E.M., Southon, J.R., 
Staff, R.A., Turney, C.S.M., and van der Plicht, J. 2013. INTCAL13 and marine radiocarbon age calibration curves 0-50,000 years cal BP. Radiocarbon 55:1869-1887.

Reimers, C.E. and Suess, E. 1983. Spatial and temporal patterns of organic matter accumulation on the Peru continental margin. In: Tiede, J., Suess, E. (Eds.), Coastal upwelling, Pt. B, its sediment record.

Reinhardt, L., Kudrass, H.R., Luckge, A., Wiedicke, M., Wunderlich, J., and Wendt, G. 2002. High-resolution sediment echosounding off Peru: Late Quaternary depositional sequences and sedimentary structures of a current-dominated shelf. Marine Geophysical Researches, 23:335-351.

Resig, J.M. 1981. Biogeography of benthic foraminifera of the northern Nazca Plate and adjacent Continental margin, Geological Society of America, Memoir, 154:619-665.

Resig, J.M. 1990. Benthic foraminiferal stratigraphy and palaeoenvironments off Peru leg 112. In Suess, E., Von Huene, R., Emeis, K.-C., Bourgois, J., Castaneda, J.C.C., Wever, P., Eglinton, G., Garrison, R., Greenberg, M., Paz, E.H., Hill, P., Ibaraki, M., Kastner, M., Kemp, A.E.S., Kvenvolden, K., Langridge, R., Lindsley-Griffin, N., Marsters, J., Martini, E., McCabe, R., Ocola, L., Resig, J., Sanchez Fernandez, A.W., Schrader, H.-J., Thornburg, T., Wefer, G.and Yamano, M. (eds.), Proceedings of the Ocean Drilling Program, Scientific Results, 112. Ocean Drilling Program, College Station, Texas, USA.

Reuss, A.E. 1850. Neue Foraminiferen aus den Schichten des österreichischen Tertiärbeckens, Denkschr. K. Akademische Wissenschaftliche Wien, 1:365-390.

Reuss, A.E. 1851. Über die fossilen Foraminiferen und Entomostraceen der Septarienthone der Umgegend von Berlin. Zeitschrift der Deutschen Geologischen Gesellschaft, Berlin, 3:49-91.

Reuss, A.E. 1863. Die Foraminiferen-Familie der Lagenideen, K. Sitzungsberichte der Kaiserlichen Akademie der Wissenschaften, MathematischeNaturwissenschaftliche Classe, Wien, 46:308-342.

Reuss, A.E. 1870. Die Foraminiferen des Septarienthones von Pietzpuhl, K. Akademische Wissenschaftiche Wien, 62.

Sarkar, S. and Gupta, A.K. 2014. Late Quaternary productivity changes in the equatorial Indian Ocean (ODP Hole 716A). Palaeogeography, Palaeoclimatology, Palaeoecology, 397:7-19.

Schmiedl, G., Mitschele, A., Beck, S., Emeis, K.-C., Hemleben, C., Schulz, H., Sperling, M., and Weldeab, S. 2003. Benthic foraminiferal record of ecosystem variability in the eastern Mediterranean Sea during times of sapropel S5 and S6 deposition. Palaeogeography, Palaeoclimatology, Palaeoecology, 190:139-164.

Schönfeld, J., Alve, E., Geslin, E., Jorissen, F., Korsun, S., and Spezzaferri, S. 2012. The FOBIMO (FOraminiferal Blo-MOnitoring) initiative-Towards a standardised protocol for soft-bottom benthic foraminiferal monitoring studies. Marine Micropalaeontology, 94:1-13.

Schönfeld, J., Kuhnt, W., Erdem, Z., Flögel, S., Glock, N., Aquit, M., Frank, M,. and Holbourn, A., 2015. Records of past mid-depth ventilation: Cretaceous ocean anoxic event 2 vs. Recent oxygen minimum zones. Biogeosciences, 12(4):1169-1189.

Schönfeld, J. and Spiegler, D. 1995. Benthic foraminiferal biostratigraphy of Site 861 , Chile triple junction, Southeastern Pacific. In Lewis, S.D., Behrmann, J.H., Musgrave, R.J., and Cande, S.C. (eds.), Proceedings of the Ocean Drilling Program, Scientific Results, College Station, Texas, USA.

Schwager, C. 1866. Fossile Foraminiferen von Kar Nikobar. In Reise der Österreichischen Fregatte Novara um die Erde in den Jahren 1857, 1858, 1859 unter den Befehlen des Commodore B. von WüllerstorfUrbair. Geologischer Theil 2, K. K. Hof- und Staatsdruckerei

Schlitzer, R. 2010. Ocean Data View, odv.awi.de.

Seguenza, G. 1862. Prime recerche intorno ai Rizopodi fossili delle argile Pleistoceniche dei dintorni di Catania, Atti dell'Accademia Gioenia di scienza naturale, 18(2).

Sen Gupta, B.K. and Machain-Castillo, M.L. 1993. Benthic foraminifera in oxygen-poor habitats. Marine Micropalaeontology, 20:183 - 201.

Shakun, J.D. and Carlson, A.E. 2010. A global perspective on last glacial maximum to holocene climate change. Quaternary Science Reviews, 29(15):18011816.

Silvestri, A. 1896. Foraminiferi pliocenici della Provincia di Siena. In Memorie della Pontificia Accademia dei Nuovi Lincei, F. Cuggiani, Roma, Italia, 15.

Smart, C.W., King, S.C., Gooday, A.J., Murray, J.W., and Thomas, E. 1994. A benthic foraminiferal proxy of pulsed organic-matter palaeofluxes. Marine Micropalaeontology, 23:89-99.

Smith, P.B. 1964. Ecology of benthonic species. Geological Survey Professional Paper, Washington.

Stewart, R.E. and Stewart, K.C. 1930. Post-Miocene foraminifera from the Ventura Quadrangle, Ventura County, California. Journal of Paleontology, 4(1):6072.

Strub, P.T., Mesías, J.M., Montecino, V., Rutllant, J., and Salinas, S. 1998. Coastal ocean circulation off western South America. In Robinson, A.R. and Brink, K.H. (eds.), The Sea. J. Wiley and Sons, New York.

Suess, E., Kulm, L.D., and Killingley, J.S. 1987. Coastal upwelling and a history of organic-rich mudstone deposition off Peru. In Brooks, J. and Fleet, A.J. (eds.), Marine Petroleum Source Rocks, Geological Society.

Tapia, R., Lange, C.B., and Marchant, M. 2008. Living (stained) calcareous benthic foraminifera from recent sediments off Concepción, central-southern Chile $\left(\begin{array}{ll}\sim 6^{\circ} & \text { S}\end{array}\right)$. Revista Chilena de Historia Natural, 81:403-416. 
Thomas, E. and Gooday, A.J. 1996. Cenozoic deep-sea benthic foraminifers: Tracers for changes in oceanic productivity? Geology, 24:355-358.

Todd, R. 1948. Subfamily Uvigerininae. In Cushman, J.A. and McCulloch, I. (eds.), The species of Bulimina and related genera in the collections of the Allan Hancock Foundation. Southern California University Publications Allan Hancock Pacific Expedition, 6(5).

Uchio, T. 1960. Ecology of living benthonic Foraminifera frpm the San Diego, California area. Cushman Foundation Foraminifera Research Special Publications 5:1-72.

Van der Zwaan, G.J., Duijnstee, I.A.P., Jannink, N.T., den Dulk, M., and Kouwenhoven, T.J. 1999. Benthic foraminifers: proxies or problems? A review of palaeoecological concepts. Earth-Science Reviews, 46:213-236.

Vismara Schilling, A. and Parisi, E. 1981. Anomalinoides minimus, a new benthic foraminiferal species from Pleistocene and Holocene deep sea deposits of the Mediterranean Sea. Rivista Italiana di paleontologia e stratigrafia, 87(02):283-292.

von Fichtel, L. and von Moll, J.P.C. 1798. Testacea Microscopica alia que minuta ex generibus Argonauta et Nautilus, ad natura pictura et descripta (Mikroskopische und andere kleine Schaltiere aus den Geschlechtern Argonaute und Schiffer), Camesina, Wien.

Waelbroeck, C., Labeyrie, L., Michel, E., Duplessy, J.C., McManus, J.F., Lambeck, K., Balbon, E., and Labracherie, M. 2002. Sea-level and deep water temperature changes derived from benthic foraminifera isotopic records. Quaternary Science Reviews, 21(1):295-305.

Walker, G. and Boys, W. 1784. Testacea minuta varioa, nuperime detecta in arena littoris Sandvicensis a Gul.
Boys, arm. SA.S. Multa addidit, et omnium figures ope microscopii ampliatus curate delineavit Geo. Walker. London.

Walker, G. and Jacob, E. 1798. Adams' essays on the microscope. In Adams, G. and Kanmacher, F. (eds.), Essays on Microscope, Dillon and Keating, London.

Wefer, G., Heinze, P., and Suess, E. 1990. Stratigraphy and sedimentation rates from oxygen isotope composition, organic carbon content, and grain size distribution at the Peru upwelling region: Holes 680B and 686B. In Suess, E., Von Huene, R., Emeis, K.-C., Bourgois, J., Castaneda, J.C.C., Wever, P., Eglinton, G., Garrison, R., Greenberg, M., Paz, E.H., Hill, P., Ibaraki, M., Kastner, M., Kemp, A.E.S., Kvenvolden, K., Langridge, R., Lindsley-Griffin, N., Marsters, J., Martini, E., McCabe, R., Ocola, L., Resig, J., Sanchez Fernandez, A.W., Schrader, H.-J., Thornburg, T., Wefer, G.and Yamano, M. (eds.), Proceedings of the Ocean Drilling Program: Scientific Results, 112. Ocean Drilling Program, College Station, TX.

Whittaker, J. 1988. Benthic Cenozoic Foraminifera from Ecuador. British Museum (Natural History), London.

Wiesner, H. 1931. Die foraminiferen der deutschen Südpolar Expedition 1901-1903, In von Drygalski, E. (ed.), Deutsche Südpolar Expedition 1901-1903, vol. 20.

Williamson, W.C. 1848. On the British recent species of the genus Lagena, Annual Magazine Natural History, 2(I).

Williamson, W.C. 1858. On the Recent Foraminifera of Great Britain, vol. 29, Ray Society London.

Wyrtki, K. 1962. The oxygen minima in relation to ocean circulation. Deep-Sea Research, 9:11-23.

Zalesny, E.R. 1959. Foraminiferal Ecology of Santa Monica Bay, California. Micropalaeontology, 5:101-126. 


\section{APPENDIX.}

Relative abundances calculated for each sample and core.

Part 1.

\begin{tabular}{|c|c|c|c|c|c|c|c|c|c|c|c|c|c|c|c|c|c|c|c|c|}
\hline \multirow{2}{*}{$\begin{array}{c}\text { M77/2-59-1 } \\
\begin{array}{c}\text { Species / Age } \\
\text { (cal yr BP) }\end{array}\end{array}$} & \multicolumn{6}{|c|}{ late Holocene } & \multicolumn{5}{|c|}{ early Holocene } & \multicolumn{5}{|c|}{ BA/ACR } & \multicolumn{4}{|c|}{ Heinrich Stadial-1 } \\
\hline & 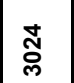 & $\sum_{m}^{m}$ & ర্口 & $\stackrel{\infty}{\frac{\infty}{+}}$ & ஜூ & $\underset{\substack{\infty \\
\&}}{N}$ & 冓 & : & 용 & ণั & ஜ̊ & $\stackrel{\sim}{\frac{m}{\sigma}}$ & ষ্ণ & 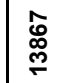 & ঙ̊ণ్ণ & 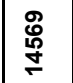 & $\begin{array}{l}0 \\
\infty \\
0 \\
0\end{array}$ & 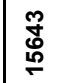 & ర్ల్ల్రి & ڤ̊ \\
\hline $\begin{array}{l}\text { Alabaminella } \\
\text { weddellensis }\end{array}$ & 4.85 & 5.96 & 5.45 & 4.50 & 5.77 & 4.17 & 3.03 & 4.35 & 2.64 & 3.10 & 2.67 & 0.00 & 0.00 & 0.38 & 0.00 & 0.00 & 0.44 & 0.00 & 0.00 & 0.00 \\
\hline $\begin{array}{l}\text { Anomalinoides } \\
\text { minimus }\end{array}$ & 3.00 & 3.34 & 3.50 & 5.03 & 2.54 & 3.79 & 4.33 & 4.35 & 4.70 & 3.53 & 5.08 & 3.11 & 0.23 & 0.57 & 0.69 & 0.63 & 0.29 & 0.00 & 0.00 & 0.00 \\
\hline $\begin{array}{l}\text { Bolivina } \\
\text { interjuncta var. } \\
\text { bicostata }\end{array}$ & 0.57 & 0.73 & 0.00 & 0.53 & 0.46 & 0.19 & 0.43 & 1.16 & 1.17 & 1.21 & 1.60 & 6.99 & 3.97 & 4.39 & 3.45 & 2.83 & 5.84 & 4.05 & 4.84 & 3.93 \\
\hline $\begin{array}{l}\text { Bolivina } \\
\text { pacifica }\end{array}$ & 0.00 & 0.00 & 0.39 & 0.00 & 0.23 & 0.19 & 0.43 & 0.00 & 0.15 & 0.52 & 0.40 & 0.78 & 2.10 & 4.77 & 5.86 & 5.03 & 1.61 & 2.02 & 3.96 & 5.36 \\
\hline $\begin{array}{l}\text { Bolivina } \\
\text { quadrata }\end{array}$ & 0.14 & 0.00 & 0.00 & 0.00 & 0.00 & 0.00 & 0.87 & 0.87 & 1.03 & 1.03 & 1.60 & 4.50 & 3.50 & 6.87 & 1.38 & 2.83 & 1.75 & 0.00 & 3.96 & 3.39 \\
\hline $\begin{array}{l}\text { Bolivinita } \\
\text { minuta }\end{array}$ & 21.83 & 21.80 & 29.57 & 22.49 & 20.09 & 13.64 & 12.12 & 16.81 & 16.74 & 19.83 & 20.32 & 18.94 & 9.11 & 5.92 & 2.76 & 0.63 & 10.80 & 3.85 & 1.32 & 0.36 \\
\hline $\begin{array}{l}\text { Cassidulina } \\
\text { carinata }\end{array}$ & 2.71 & 3.78 & 5.06 & 6.08 & 8.31 & 5.11 & 5.19 & 8.70 & 6.75 & 6.21 & 6.42 & 5.28 & 5.37 & 7.63 & 0.00 & 1.89 & 4.38 & 7.29 & 8.79 & 4.82 \\
\hline $\begin{array}{l}\text { Cassidulina } \\
\text { delicata }\end{array}$ & 9.70 & 11.92 & 11.28 & 12.17 & 9.93 & 12.88 & 13.42 & 8.41 & 11.89 & 12.33 & 8.16 & 2.80 & 7.01 & 3.63 & 4.14 & 3.77 & 7.74 & 15.59 & 7.69 & 10.00 \\
\hline $\begin{array}{l}\text { Cassidulina } \\
\text { minuta }\end{array}$ & 8.27 & 4.22 & 0.00 & 1.59 & 4.85 & 2.27 & 0.00 & 4.06 & 1.17 & 0.00 & 0.00 & 0.00 & 0.00 & 0.00 & 0.00 & 0.00 & 0.44 & 0.00 & 0.00 & 0.00 \\
\hline $\begin{array}{l}\text { Epistominella } \\
\text { afueraensis }\end{array}$ & 0.00 & 0.00 & 1.56 & 0.00 & 0.00 & 4.36 & 1.30 & 5.80 & 2.94 & 1.47 & 1.07 & 2.95 & 1.87 & 0.19 & 0.00 & 0.63 & 0.00 & 0.00 & 0.66 & 0.00 \\
\hline $\begin{array}{l}\text { Epistominella } \\
\text { exigua }\end{array}$ & 5.56 & 5.67 & 5.45 & 8.20 & 5.77 & 6.63 & 7.79 & 7.54 & 8.66 & 10.17 & 8.02 & 11.96 & 10.75 & 15.08 & 21.38 & 16.35 & 17.08 & 9.11 & 13.19 & 22.68 \\
\hline $\begin{array}{l}\text { Epistominella } \\
\text { obesa }\end{array}$ & 2.57 & 3.05 & 1.56 & 3.70 & 5.08 & 0.95 & 0.00 & 0.00 & 0.00 & 1.81 & 0.94 & 0.78 & 3.74 & 2.10 & 4.48 & 3.14 & 2.77 & 3.24 & 1.76 & 1.61 \\
\hline $\begin{array}{l}\text { Epistominella } \\
\text { pacifica }\end{array}$ & 0.71 & 1.45 & 0.39 & 0.00 & 0.00 & 0.00 & 0.00 & 0.00 & 1.17 & 0.95 & 2.67 & 0.00 & 2.57 & 6.30 & 5.52 & 0.00 & 2.19 & 2.02 & 1.76 & 0.89 \\
\hline $\begin{array}{l}\text { Epistominella } \\
\text { smithi }\end{array}$ & 0.00 & 0.00 & 0.00 & 0.00 & 0.23 & 0.19 & 0.00 & 0.29 & 0.00 & 0.00 & 0.00 & 4.97 & 5.84 & 0.00 & 0.00 & 4.40 & 3.50 & 2.83 & 5.71 & 5.00 \\
\hline $\begin{array}{l}\text { Gyroidina } \\
\text { rothwelli }\end{array}$ & 1.14 & 1.16 & 1.95 & 1.06 & 0.69 & 0.95 & 0.87 & 3.19 & 1.47 & 2.41 & 2.81 & 4.97 & 5.37 & 5.15 & 4.14 & 3.14 & 3.21 & 4.66 & 0.88 & 1.61 \\
\hline $\begin{array}{l}\text { Uvigerina } \\
\text { auberiana }\end{array}$ & 6.56 & 7.27 & 5.06 & 6.35 & 6.24 & 7.77 & 6.93 & 5.51 & 6.31 & 5.26 & 5.08 & 3.26 & 3.27 & 2.10 & 1.03 & 1.26 & 0.00 & 0.00 & 0.00 & 0.00 \\
\hline $\begin{array}{l}\text { Uvigerina } \\
\text { semiornata }\end{array}$ & 2.85 & 1.60 & 1.56 & 3.97 & 5.08 & 4.73 & 3.90 & 2.61 & 3.08 & 1.12 & 3.21 & 2.64 & 1.64 & 0.76 & 0.00 & 1.57 & 1.90 & 0.81 & 2.86 & 1.25 \\
\hline $\begin{array}{l}\text { Virgulina } \\
\text { spinosa }\end{array}$ & 0.00 & 0.00 & 0.00 & 0.00 & 0.00 & 0.00 & 0.00 & 0.00 & 0.00 & 0.09 & 0.00 & 0.47 & 1.87 & 7.06 & 6.21 & 20.44 & 1.17 & 0.61 & 0.88 & 0.00 \\
\hline Miliolids & 0.14 & 0.00 & 0.00 & 0.00 & 0.00 & 0.00 & 0.00 & 0.00 & 0.15 & 0.09 & 0.27 & 0.16 & 0.00 & 0.00 & 0.00 & 0.00 & 0.29 & 0.00 & 0.66 & 0.18 \\
\hline $\begin{array}{l}\text { Other } \\
\text { calcareous }\end{array}$ & 29.24 & 28.05 & 27.24 & 24.34 & 24.48 & 32.20 & 39.39 & 26.38 & 29.96 & 28.88 & 29.68 & 25.47 & 31.78 & 27.10 & 38.97 & 31.45 & 34.60 & 43.93 & 41.10 & 38.93 \\
\hline Agglutinated & 0.14 & 0.00 & 0.00 & 0.00 & 0.23 & 0.00 & 0.00 & 0.00 & 0.00 & 0.00 & 0.00 & 0.00 & 0.00 & 0.00 & 0.00 & 0.00 & 0.00 & 0.00 & 0.00 & 0.00 \\
\hline $\begin{array}{l}\text { Total number } \\
\text { specimens }\end{array}$ & 701 & 688 & 257 & 378 & 433 & 528 & 231 & 345 & 681 & 1160 & 748 & 644 & 428 & 524 & 290 & 318 & 685 & 494 & 455 & 560 \\
\hline $\begin{array}{l}\text { Total number } \\
\text { species }\end{array}$ & 57 & 71 & 40 & 48 & 51 & 56 & 45 & 50 & 67 & 70 & 63 & 52 & 51 & 54 & 43 & 49 & 56 & 49 & 52 & 53 \\
\hline
\end{tabular}


Part 2A.

\begin{tabular}{|l|c|c|c|c|c|c|c|c|c|c|c|}
\hline \multicolumn{1}{|c|}{ M77/2-52-2 } & \multicolumn{5}{|c|}{ late Holocene } & \multicolumn{5}{c|}{ early Holocene } \\
\hline $\begin{array}{c}\text { Species I Age (cal yr } \\
\text { BP) }\end{array}$ & $\mathbf{3 1 3 0}$ & $\mathbf{3 8 4 5}$ & $\mathbf{4 2 0 2}$ & $\mathbf{4 5 5 9}$ & $\mathbf{4 9 1 7}$ & $\mathbf{8 0 9 7}$ & $\mathbf{8 4 8 6}$ & $\mathbf{8 8 3 9}$ & $\mathbf{9 1 9 2}$ & $\mathbf{9 5 4 6}$ & $\mathbf{9 8 9 9}$ \\
\hline Bolivina costata & 27.12 & 33.88 & 25.50 & 33.81 & 23.13 & 42.46 & 22.96 & 20.85 & 18.98 & 23.13 & 17.32 \\
\hline Bolivina spissa & 4.24 & 4.47 & 6.19 & 3.57 & 3.06 & 6.36 & 4.14 & 3.64 & 4.92 & 6.22 & 5.08 \\
\hline Bolivinita minuta & 1.69 & 1.88 & 2.23 & 1.67 & 3.40 & 2.21 & 5.80 & 3.24 & 4.92 & 3.84 & 5.77 \\
\hline Bulimina pagoda & 0.00 & 0.71 & 0.99 & 1.43 & 0.68 & 0.41 & 0.59 & 0.81 & 0.00 & 0.00 & 0.00 \\
\hline Cassidulina carinata & 0.00 & 1.65 & 1.73 & 0.95 & 4.08 & 0.00 & 1.78 & 0.00 & 0.51 & 0.73 & 1.39 \\
\hline Cassidulina delicata & 7.63 & 5.88 & 7.18 & 7.38 & 8.84 & 8.44 & 15.50 & 10.53 & 12.03 & 11.83 & 20.55 \\
\hline Cassidulina laevigata & 0.85 & 0.00 & 0.00 & 0.48 & 0.00 & 0.28 & 0.00 & 0.81 & 0.00 & 0.00 & 0.00 \\
\hline Cibicides mckannai & 0.42 & 3.29 & 2.72 & 2.38 & 1.02 & 4.43 & 1.54 & 3.64 & 4.24 & 3.22 & 2.54 \\
\hline Epistominella exigua & 7.63 & 3.06 & 2.97 & 6.67 & 9.86 & 0.00 & 2.25 & 1.62 & 1.69 & 1.76 & 3.70 \\
\hline Epistominella pacifica & 1.69 & 4.47 & 0.00 & 0.00 & 3.40 & 1.38 & 6.51 & 6.28 & 7.29 & 6.95 & 2.54 \\
\hline Epistominella smithi & 3.39 & 4.24 & 7.43 & 6.67 & 3.06 & 2.35 & 0.00 & 0.00 & 0.00 & 0.93 & 2.77 \\
\hline Uvigerina auberiana & 7.63 & 9.88 & 10.64 & 8.57 & 9.18 & 5.67 & 5.44 & 5.87 & 4.58 & 4.67 & 5.77 \\
\hline Uvigerina bifurcata & 0.00 & 0.00 & 0.00 & 0.00 & 0.00 & 0.00 & 0.00 & 0.00 & 0.00 & 0.62 & 0.00 \\
\hline Uvigerina peregrina & 0.00 & 0.94 & 0.00 & 0.00 & 0.00 & 0.00 & 1.18 & 1.21 & 1.19 & 0.83 & 0.00 \\
\hline Uvigerina semiornata & 8.05 & 6.82 & 8.42 & 8.10 & 6.12 & 5.39 & 5.56 & 8.91 & 10.85 & 4.67 & 3.46 \\
\hline Miliolids & 0.00 & 0.00 & 0.00 & 0.00 & 0.00 & 0.14 & 0.00 & 0.00 & 0.34 & 0.00 & 0.23 \\
\hline Other calcareous & 28.39 & 16.94 & 21.78 & 16.19 & 22.11 & 19.92 & 25.80 & 31.78 & 27.80 & 30.08 & 28.41 \\
\hline Agglutinated species & 1.27 & 1.88 & 2.23 & 2.14 & 2.04 & 0.55 & 0.95 & 0.81 & 0.68 & 0.52 & 0.46 \\
\hline & & & & & & & & & & & \\
\hline $\begin{array}{l}\text { Total number } \\
\text { specimens }\end{array}$ & 236 & 425 & 404 & 420 & 294 & 723 & 845 & 494 & 590 & 964 & 433 \\
\hline $\begin{array}{l}\text { Total number } \\
\text { species }\end{array}$ & 45 & 48 & 50 & 41 & 48 & 53 & 62 & 67 & 60 & 77 & 46 \\
\hline
\end{tabular}


ERDEM \& SCHÖNFELD: BENTHIC FORAMINIFERA OFF PERU

Part 2B..

\begin{tabular}{|c|c|c|c|c|c|c|c|c|c|c|c|c|c|c|c|c|}
\hline$M 77 / 2-52-2$ & & & BA/ACF & & & & & Heinrich & Stadial & & & & Las & t Glacial & $\operatorname{Max}$ & \\
\hline $\begin{array}{c}\text { Species / Age (cal yr } \\
\text { BP) }\end{array}$ & 12714 & 13177 & 13641 & 14143 & 14465 & 15147 & 15469 & 16151 & 16653 & 17155 & 17657 & 20168 & 20670 & 21172 & 21674 & 22176 \\
\hline Bolivina costata & 4.35 & 1.15 & 1.00 & 5.23 & 2.34 & 0.88 & 1.35 & 0.90 & 2.24 & 0.74 & 1.38 & 4.15 & 4.60 & 4.56 & 3.66 & 6.04 \\
\hline Bolivina spissa & 4.35 & 3.93 & 2.99 & 3.35 & 2.05 & 4.84 & 2.12 & 4.30 & 2.52 & 1.98 & 2.75 & 0.98 & 1.02 & 1.45 & 0.37 & 0.15 \\
\hline Bolivinita minuta & 11.84 & 19.86 & 4.23 & 6.90 & 1.46 & 3.96 & 1.54 & 4.52 & 1.12 & 0.74 & 0.79 & 0.37 & 0.26 & 0.00 & 0.18 & 0.15 \\
\hline Bulimina pagoda & 1.21 & 0.69 & 1.00 & 1.05 & 0.88 & 1.10 & 0.19 & 0.00 & 0.84 & 0.50 & 0.79 & 5.73 & 3.32 & 6.01 & 3.84 & 6.50 \\
\hline Cassidulina carinata & 2.42 & 2.08 & 6.97 & 4.60 & 4.39 & 4.84 & 3.08 & 0.45 & 3.36 & 4.95 & 2.75 & 8.29 & 23.27 & 9.12 & 10.42 & 7.28 \\
\hline Cassidulina delicata & 12.80 & 8.78 & 15.17 & 12.13 & 9.94 & 7.47 & 6.92 & 6.33 & 9.52 & 6.93 & 13.75 & 8.41 & 5.63 & 8.29 & 5.67 & 14.86 \\
\hline Cassidulina laevigata & 0.00 & 0.00 & 0.25 & 0.00 & 0.00 & 0.00 & 0.38 & 1.36 & 0.00 & 0.00 & 2.36 & 0.98 & 0.00 & 3.11 & 6.95 & 14.09 \\
\hline Cibicides mckannai & 4.59 & 6.70 & 6.72 & 3.56 & 1.46 & 3.30 & 1.15 & 2.26 & 1.12 & 0.99 & 1.96 & 1.95 & 0.26 & 1.66 & 0.18 & 1.24 \\
\hline Epistominella exigua & 3.38 & 2.77 & 1.99 & 4.18 & 9.36 & 13.19 & 23.27 & 22.17 & 25.49 & 31.19 & 33.01 & 0.98 & 10.23 & 0.62 & 5.12 & 3.56 \\
\hline Epistominella pacifica & 4.11 & 5.08 & 8.21 & 2.51 & 0.88 & 3.52 & 6.35 & 3.62 & 2.24 & 1.98 & 1.96 & 0.00 & 0.00 & 0.21 & 1.10 & 2.17 \\
\hline Epistominella smithi & 6.28 & 8.08 & 1.74 & 8.58 & 11.40 & 6.81 & 4.62 & 3.85 & 4.48 & 6.44 & 1.77 & 10.12 & 5.88 & 4.97 & 4.02 & 2.32 \\
\hline Uvigerina auberiana & 6.04 & 5.54 & 5.47 & 4.81 & 6.14 & 2.42 & 2.69 & 2.71 & 3.08 & 0.50 & 2.75 & 7.68 & 5.63 & 7.25 & 5.85 & 5.88 \\
\hline Uvigerina $b$ & 0.00 & 1.15 & 0.00 & 1.26 & 0.00 & 0.00 & 0.00 & 0.00 & 0.00 & 0.00 & 0.00 & 4.63 & 3.07 & 8.91 & 0.00 & 0.00 \\
\hline Uvigerina peregrina & 0.00 & 0.92 & 0.00 & 1.26 & 0.88 & 0.66 & 0.58 & 2.04 & 0.28 & 0.00 & 0.00 & 2.32 & 4.09 & 5.60 & 10.05 & 5.73 \\
\hline Uvigerina semiornata & 7.00 & 5.54 & 11.44 & 4.60 & 7.60 & 10.55 & 4.23 & 6.11 & 8.68 & 5.69 & 6.29 & 17.20 & 5.88 & 6.53 & 3.66 & 6.04 \\
\hline Miliolids & 0.00 & 0.46 & 0.00 & 0.42 & 0.29 & 0.22 & 0.00 & 0.23 & 0.00 & 0.00 & 0.00 & 0.00 & 0.00 & 0.31 & 0.37 & 0.00 \\
\hline Other calcareous & 30.92 & 25.87 & 32.84 & 35.15 & 40.35 & 35.82 & 40.96 & 38.69 & 34.17 & 37.38 & 26.92 & 26.10 & 26.85 & 31.40 & 38.57 & 23.84 \\
\hline Agglutinated species & 0.72 & 1.39 & 0.00 & 0.42 & 0.58 & 0.44 & 0.58 & 0.45 & 0.84 & 0.00 & 0.79 & 0.12 & 0.00 & 0.00 & 0.00 & 0.15 \\
\hline $\begin{array}{l}\text { Total number } \\
\text { specimens }\end{array}$ & 414 & 433 & 402 & 478 & 342 & 455 & 520 & 442 & 357 & 404 & 509 & 820 & 391 & 965 & 547 & 646 \\
\hline $\begin{array}{l}\text { Total number } \\
\text { species }\end{array}$ & 60 & 50 & 53 & 69 & 67 & 59 & 63 & 50 & 51 & 45 & 50 & 76 & 50 & 75 & 73 & 70 \\
\hline
\end{tabular}


Part 3.

\begin{tabular}{|c|c|c|c|c|c|c|c|c|c|c|c|c|c|c|c|c|c|c|c|c|}
\hline \multirow{2}{*}{\begin{tabular}{|c|} 
M77/2-50-4 \\
Species / Age \\
(cal yr BP)
\end{tabular}} & \multicolumn{6}{|c|}{ BA/ACR } & \multicolumn{6}{|c|}{ Heinrich Stadial-1 } & \multicolumn{8}{|c|}{ Last Glacial Max } \\
\hline & 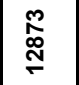 & ণ్ర్ & $\stackrel{\bar{m}}{\bar{g}}$ & 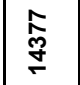 & $\begin{array}{l}\text { N̦ } \\
\stackrel{+}{+}\end{array}$ & $\begin{array}{l}\stackrel{\circ}{0} \\
\stackrel{\infty}{+}\end{array}$ & 员 & 員 & $\underset{\mathscr{f}}{\mathscr{f}}$ & 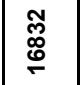 & $\stackrel{n}{\stackrel{n}{N}}$ & $\stackrel{\stackrel{\circ}{\circ}}{\stackrel{\Re}{\sim}}$ & ஜั & 苂 & స్ণ & ঃัे & $\stackrel{\infty}{\stackrel{\infty}{\leftarrow}}$ & 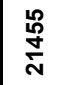 & 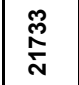 & 오ํ \\
\hline $\begin{array}{l}\text { Bolivina } \\
\text { costata }\end{array}$ & 39.30 & 28.85 & 43.63 & 44.31 & 32.44 & 25.06 & 30.97 & 26.58 & 12.08 & 5.85 & 11.38 & 6.52 & 17.22 & 7.60 & 11.18 & 9.43 & 9.13 & 8.30 & 10.14 & 10.71 \\
\hline $\begin{array}{l}\text { Bolivina } \\
\text { pacifica }\end{array}$ & 0.00 & 0.00 & 0.00 & 0.00 & 0.00 & 0.76 & 0.00 & 0.21 & 0.67 & 0.00 & 5.33 & 4.67 & 0.37 & 0.58 & 0.63 & 2.20 & 0.48 & 0.53 & 0.62 & 0.74 \\
\hline $\begin{array}{l}\text { Bolivina } \\
\text { seminuda var. } \\
\text { humilis }\end{array}$ & 1.08 & 3.13 & 4.54 & 4.19 & 2.89 & 4.79 & \begin{tabular}{|l|}
5.51 \\
\end{tabular} & 5.91 & 6.26 & 4.68 & 5.57 & 3.12 & 3.30 & 5.85 & 3.80 & 6.72 & 5.77 & 3.36 & 2.96 & 2.98 \\
\hline $\begin{array}{l}\text { Bolivinita } \\
\text { minuta }\end{array}$ & 10.03 & 6.73 & 3.32 & 1.20 & 4.44 & 3.02 & \begin{tabular}{|l|}
1.31 \\
\end{tabular} & 1.69 & 3.80 & 4.68 & 3.39 & 2.83 & 0.73 & 2.34 & 1.27 & 1.55 & 1.44 & 1.77 & 3.28 & 3.87 \\
\hline $\begin{array}{l}\text { cf. Buccella } \\
\text { peruviana }\end{array}$ & 0.00 & 0.00 & 2.09 & 1.80 & 0.00 & 0.50 & 0.52 & 1.05 & 0.00 & 0.00 & 0.00 & 2.69 & 0.37 & 0.00 & 2.11 & 3.88 & 1.92 & \begin{tabular}{|l|}
1.59 \\
\end{tabular} & 1.56 & 5.36 \\
\hline $\begin{array}{l}\text { Buliminella } \\
\text { tenuata }\end{array}$ & \begin{tabular}{|l|}
0.54 \\
\end{tabular} & 2.88 & \begin{tabular}{|l|}
1.57 \\
\end{tabular} & 2.40 & 2.44 & \begin{tabular}{|l|}
5.16 \\
\end{tabular} & \begin{tabular}{|l|}
2.62 \\
\end{tabular} & 0.63 & 2.24 & \begin{tabular}{|l|}
2.34 \\
\end{tabular} & 1.45 & \begin{tabular}{|l|}
0.57 \\
\end{tabular} & 2.20 & \begin{tabular}{|l|}
0.00 \\
\end{tabular} & 1.05 & 0.00 & \begin{tabular}{|l|}
0.00 \\
\end{tabular} & \begin{tabular}{|l|}
1.06 \\
\end{tabular} & 0.00 & 0.89 \\
\hline $\begin{array}{l}\text { Cassidulina } \\
\text { auka }\end{array}$ & \begin{tabular}{|l|}
0.00 \\
\end{tabular} & 0.00 & 0.00 & 0.00 & 0.00 & \begin{tabular}{|l|}
0.76 \\
\end{tabular} & 0.00 & 0.00 & 0.00 & \begin{tabular}{|l|}
0.00 \\
\end{tabular} & 0.00 & \begin{tabular}{|l|}
0.00 \\
\end{tabular} & 5.13 & \begin{tabular}{|l|}
1.75 \\
\end{tabular} & 2.32 & 3.23 & \begin{tabular}{|l|}
5.77 \\
\end{tabular} & \begin{tabular}{|l}
4.59 \\
\end{tabular} & 1.40 & 1.04 \\
\hline $\begin{array}{l}\text { Cassidulina } \\
\text { carinata }\end{array}$ & 0.00 & 0.00 & 0.00 & 0.00 & 0.89 & 1.51 & 0.00 & 2.11 & 0.89 & 0.58 & 2.42 & 2.97 & 7.33 & 5.85 & 6.96 & 5.68 & 1.92 & 10.78 & 7.49 & 4.02 \\
\hline $\begin{array}{l}\text { Cassidulina } \\
\text { delicata }\end{array}$ & \begin{tabular}{|l|}
8.40 \\
\end{tabular} & 8.65 & \begin{tabular}{|l|}
4.01 \\
\end{tabular} & 2.99 & 5.11 & 4.66 & 6.82 & 3.59 & 11.19 & \begin{tabular}{|l|}
8.77 \\
\end{tabular} & 7.02 & \begin{tabular}{|l|}
6.09 \\
\end{tabular} & 6.59 & 5.26 & 9.49 & 7.75 & 13.94 & \begin{tabular}{|l}
8.30 \\
\end{tabular} & 7.49 & 7.74 \\
\hline $\begin{array}{l}\text { Epistominella } \\
\text { afueraensis }\end{array}$ & 7.05 & 1.20 & 2.09 & 2.40 & 0.00 & 6.30 & 0.79 & 1.48 & 4.25 & 4.09 & 2.91 & 1.42 & 2.20 & 1.17 & 0.63 & 1.03 & 1.44 & 2.47 & 0.16 & 0.45 \\
\hline $\begin{array}{l}\text { Epistominella } \\
\text { exigua }\end{array}$ & \begin{tabular}{|l|}
2.44 \\
\end{tabular} & 2.64 & \begin{tabular}{|l|}
1.75 \\
\end{tabular} & 4.19 & 3.78 & 2.52 & 0.00 & 3.16 & 5.59 & \begin{tabular}{|l|}
7.02 \\
\end{tabular} & 6.78 & 14.16 & 1.83 & \begin{tabular}{|l|}
8.77 \\
\end{tabular} & 4.43 & 9.82 & \begin{tabular}{|l|}
1.44 \\
\end{tabular} & 7.77 & 12.17 & 8.18 \\
\hline $\begin{array}{l}\text { Epistominella } \\
\text { obesa }\end{array}$ & 0.00 & 1.92 & 3.14 & 6.59 & 6.44 & 6.17 & 7.35 & 6.96 & 18.34 & 7.02 & $\mid$\begin{tabular}{|l}
12.11 \\
\end{tabular} & 8.50 & 12.45 & 14.62 & 10.13 & 10.59 & 10.58 & 8.13 & 2.50 & 9.08 \\
\hline $\begin{array}{l}\text { Epistominella } \\
\text { pacifica }\end{array}$ & \begin{tabular}{|l|}
0.27 \\
\end{tabular} & 7.21 & 5.76 & 6.59 & 4.89 & \begin{tabular}{|l|}
2.77 \\
\end{tabular} & \begin{tabular}{|l|}
1.57 \\
\end{tabular} & 4.64 & 2.91 & 1.17 & 1.21 & \begin{tabular}{|l|}
0.85 \\
\end{tabular} & 3.30 & \begin{tabular}{|l|}
0.00 \\
\end{tabular} & 0.00 & 0.13 & \begin{tabular}{|l|l|}
0.00 \\
\end{tabular} & 1.24 & 0.47 & 0.00 \\
\hline $\begin{array}{l}\text { Epistominella } \\
\text { smithi }\end{array}$ & 6.78 & 2.40 & \begin{tabular}{|l|}
0.00 \\
\end{tabular} & 0.00 & 2.22 & 2.90 & \begin{tabular}{|l|}
2.89 \\
\end{tabular} & 3.80 & 0.22 & 1.75 & 2.42 & \begin{tabular}{|l|}
0.14 \\
\end{tabular} & 0.00 & \begin{tabular}{|l|} 
\\
\end{tabular} & 0.63 & 0.00 & \begin{tabular}{|l|} 
\\
\end{tabular} & 0.18 & 0.00 & 0.30 \\
\hline $\begin{array}{l}\text { Fursenkoina } \\
\text { fusiformis }\end{array}$ & 0.81 & 1.92 & 0.87 & 1.20 & 2.44 & 2.02 & 2.10 & 1.05 & 1.12 & 1.17 & 5.08 & 3.97 & 0.00 & 0.00 & 0.21 & 0.78 & 0.48 & 0.71 & 0.16 & 0.30 \\
\hline $\begin{array}{l}\text { Pseudoparella } \\
\text { subperuviana }\end{array}$ & 6.78 & 6.25 & 6.11 & 0.00 & 6.00 & 4.91 & 7.09 & 7.81 & 2.24 & 14.04 & 9.93 & 5.81 & 7.33 & 2.34 & 2.53 & 2.84 & 8.65 & 4.95 & 15.60 & 9.08 \\
\hline $\begin{array}{l}\text { Pseudoparella } \\
\text { sp. }\end{array}$ & 0.54 & 2.64 & 4.36 & 0.00 & 5.11 & 1.13 & 4.99 & 4.64 & 8.28 & 7.02 & 0.00 & 7.37 & 0.73 & 17.54 & 5.70 & 1.03 & 4.33 & 4.95 & 4.21 & 9.52 \\
\hline $\begin{array}{l}\text { Uvigerina } \\
\text { semiornata }\end{array}$ & 0.00 & 3.13 & 1.40 & 2.40 & 2.44 & 1.76 & 2.62 & 2.32 & 1.79 & 0.58 & 0.48 & 1.27 & 2.56 & 4.68 & 6.12 & 3.88 & 3.37 & 6.71 & 2.03 & 1.64 \\
\hline $\begin{array}{l}\text { Virgulina } \\
\text { cornuta }\end{array}$ & 0.00 & 0.00 & \begin{tabular}{|l|}
0.70 \\
\end{tabular} & 2.40 & 1.11 & \begin{tabular}{|l|}
1.89 \\
\end{tabular} & \begin{tabular}{|l|}
1.84 \\
\end{tabular} & \begin{tabular}{|l|}
0.84 \\
\end{tabular} & 0.89 & 1.75 & 5.57 & 5.38 & 2.20 & 1.17 & 1.69 & 0.39 & \begin{tabular}{|l|}
0.48 \\
\end{tabular} & \begin{tabular}{|l}
1.24 \\
\end{tabular} & 0.62 & 0.74 \\
\hline Miliolids & 0.00 & 0.00 & 0.00 & 0.00 & 0.00 & \begin{tabular}{|l|}
0.00 \\
\end{tabular} & 0.00 & 0.00 & 0.00 & 1.17 & 0.24 & \begin{tabular}{|l|}
0.14 \\
\end{tabular} & 1.10 & 1.17 & 0.63 & 0.78 & 0.96 & 0.53 & 0.31 & 0.30 \\
\hline $\begin{array}{l}\text { Other } \\
\text { calcareous }\end{array}$ & 15.99 & 20.43 & 14.66 & \begin{tabular}{|l|}
17.37 \\
\end{tabular} & 17.33 & 21.41 & 21.00 & 21.52 & 17.23 & 26.32 & 16.71 & 21.39 & 22.71 & 19.30 & 28.48 & 28.16 & 27.88 & 20.85 & 26.83 & 22.92 \\
\hline $\begin{array}{l}\text { Agglutinated } \\
\text { species }\end{array}$ & \begin{tabular}{|l|}
0.00 \\
\end{tabular} & 0.00 & \begin{tabular}{|l|}
0.00 \\
\end{tabular} & 0.00 & 0.00 & \begin{tabular}{|l|}
0.00 \\
\end{tabular} & \begin{tabular}{|l|}
0.00 \\
\end{tabular} & \begin{tabular}{|l|}
0.00 \\
\end{tabular} & 0.00 & \begin{tabular}{|l|}
0.00 \\
\end{tabular} & \begin{tabular}{|l|}
0.00 \\
\end{tabular} & \begin{tabular}{|l|}
0.14 \\
\end{tabular} & 0.37 & \begin{tabular}{|l|}
0.00 \\
\end{tabular} & 0.00 & 0.13 & \begin{tabular}{|l|}
0.00 \\
\end{tabular} & 0.00 & 0.00 & 0.15 \\
\hline $\begin{array}{l}\text { Total number } \\
\text { specimens }\end{array}$ & 236 & 425 & 404 & 420 & 294 & 723 & 845 & 494 & 590 & 964 & 433 & 414 & 433 & 402 & 478 & 342 & 455 & 520 & 442 & 357 \\
\hline $\begin{array}{l}\text { Total number } \\
\text { species }\end{array}$ & 45 & 48 & 50 & 41 & 48 & 53 & 62 & 67 & 60 & 77 & 46 & 60 & 50 & 53 & 69 & 67 & 59 & 63 & 50 & 51 \\
\hline
\end{tabular}


ERDEM \& SCHÖNFELD: BENTHIC FORAMINIFERA OFF PERU

Part 4.

\begin{tabular}{|c|c|c|c|c|c|c|c|c|c|c|c|c|}
\hline M77/2-47-2 & \multicolumn{3}{|c|}{ BA/ACR } & \multicolumn{4}{|c|}{ Heinrich Stadial-1 } & \multicolumn{5}{|c|}{ Last Glacial Max } \\
\hline $\begin{array}{c}\text { Species / Age } \\
\text { (cal yr BP) }\end{array}$ & 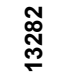 & 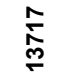 & ণั & 怘 & $\stackrel{\mathscr{0}}{\circ}$ & 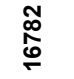 & $\stackrel{\infty}{\stackrel{\infty}{*}}$ & $\begin{array}{l}\text { : } \\
\stackrel{\circ}{\circ}\end{array}$ & ¿ֶّ & চे & 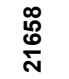 & స్ల్ \\
\hline Bolivina costata & 19.71 & 15.90 & 25.24 & 23.28 & 24.87 & 19.92 & 22.61 & 21.39 & 13.92 & 26.03 & 25.76 & 30.50 \\
\hline Bolivina seminuda var. humilis & 5.53 & 3.77 & 0.00 & 1.90 & 2.09 & 1.17 & 3.45 & 3.18 & 1.62 & 1.91 & 2.62 & 0.71 \\
\hline Bolivinita minuta & 2.88 & 3.35 & 4.11 & 5.94 & 3.14 & 2.73 & 1.53 & 2.60 & 1.94 & 2.50 & 0.87 & 2.13 \\
\hline Buccella peruviana & 4.81 & 8.37 & 4.50 & 3.80 & 2.88 & 4.69 & 1.92 & 4.62 & 3.88 & 5.00 & 3.49 & 4.61 \\
\hline Cassidulina delicata & 7.21 & 11.30 & 13.50 & 15.44 & 13.87 & 10.94 & 12.26 & 7.80 & 6.15 & 11.32 & 11.79 & 7.09 \\
\hline Cassidulina minuta & 3.13 & 0.00 & 4.11 & 0.00 & 2.62 & 3.13 & 5.36 & 8.96 & 2.91 & 2.21 & 6.11 & 0.00 \\
\hline Epistominella obesa & 9.86 & 14.85 & 3.52 & 2.38 & 11.26 & 14.84 & 15.33 & 15.90 & 15.53 & 9.12 & 6.55 & 7.45 \\
\hline Pseudoparella subperuviana & 8.65 & 11.51 & 9.98 & 13.54 & 7.85 & 8.20 & 7.28 & 3.18 & 13.59 & 10.74 & 4.37 & 3.90 \\
\hline Pseudoparella sp. & 9.13 & 5.02 & 4.31 & 6.18 & 8.90 & 7.81 & 4.21 & 11.85 & 10.36 & 6.76 & 5.24 & 13.83 \\
\hline Miliolids (Quinqueloculina sp.) & 0.00 & 0.00 & 0.20 & 0.00 & 0.00 & 0.00 & 0.00 & 0.00 & 0.00 & 0.00 & 0.00 & 0.00 \\
\hline Other calcareous & 29.09 & 25.94 & 30.72 & 27.55 & 22.51 & 26.56 & 26.05 & 20.52 & 30.10 & 24.41 & 33.19 & 29.79 \\
\hline Agglutinated species & 0.00 & 0.00 & 0.00 & 0.00 & 0.00 & 0.00 & 0.00 & 0.00 & 0.00 & 0.00 & 0.00 & 0.00 \\
\hline Total number specimens & 416 & 478 & 511 & 421 & 382 & 256 & 261 & 346 & 309 & 680 & 229 & 282 \\
\hline Total number species & 40 & 37 & 39 & 36 & 33 & 34 & 32 & 33 & 38 & 45 & 33 & 37 \\
\hline
\end{tabular}

Part 5.

\begin{tabular}{|c|c|c|c|c|c|c|c|}
\hline \multirow{2}{*}{$\begin{array}{c}\text { M77/1-416 } \\
\begin{array}{c}\text { Species / Age } \\
\text { (cal yr BP) }\end{array}\end{array}$} & \multicolumn{7}{|c|}{ Last Glacial Max } \\
\hline & 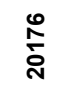 & 命 & 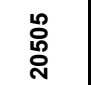 & $\stackrel{n}{\grave{0}}$ & 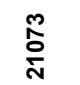 & $\stackrel{\bar{ల}}{\stackrel{\Gamma}{N}}$ & $\stackrel{\Re}{\stackrel{\mathfrak{N}}{\circ}}$ \\
\hline Bolivina plicata & 0.90 & 0.39 & 0.93 & 2.99 & 5.19 & 5.59 & 3.44 \\
\hline Bolivina seminuda var. humilis & 3.62 & 6.25 & 6.48 & 12.69 & 1.48 & 13.13 & 22.14 \\
\hline Buliminella elegantissima & 0.00 & 0.78 & 21.30 & 0.75 & 20.74 & 0.28 & 0.00 \\
\hline Cassidulina auka & 38.01 & 16.80 & 21.30 & 14.93 & 6.67 & 5.03 & 1.91 \\
\hline Epistominella afueraensis & 0.90 & 27.34 & 0.00 & 9.70 & 0.00 & 6.70 & 9.54 \\
\hline Epistominella exigua & 6.33 & 2.34 & 0.00 & 0.00 & 0.00 & 0.00 & 0.00 \\
\hline Epistominella obesa & 0.00 & 0.00 & 1.85 & 0.00 & 8.89 & 0.84 & 5.73 \\
\hline Epistominella pacifica & 9.95 & 12.11 & 9.26 & 10.45 & 0.74 & 33.52 & 12.98 \\
\hline Gyroidina rothwelli & 13.12 & 10.94 & 2.78 & 14.93 & 1.48 & 2.23 & 7.63 \\
\hline Nonionella auris & 0.00 & 0.78 & 9.26 & 0.00 & 14.81 & 0.00 & 0.00 \\
\hline Planulina limbata & 7.24 & 2.34 & 3.70 & 2.24 & 0.74 & 1.40 & 3.44 \\
\hline Pseudoparella subperuviana & 0.00 & 0.00 & 4.63 & 0.00 & 17.04 & 0.84 & 2.29 \\
\hline Uvigerina peregrina & 0.00 & 1.95 & 0.00 & 1.49 & 0.00 & 5.59 & 5.73 \\
\hline Uvigerina striata & 0.90 & 0.78 & 0.00 & 0.00 & 0.74 & 2.23 & 5.34 \\
\hline Miliolids (Quinqueloculina sp.) & 0.45 & 0.00 & 0.00 & 0.00 & 0.00 & 0.00 & 0.00 \\
\hline Other calcareous & 19.00 & 17.19 & 18.52 & 29.85 & 21.48 & 22.63 & 19.85 \\
\hline Agglutinated species & 0.00 & 0.00 & 0.00 & 0.00 & 0.00 & 0.00 & 0.00 \\
\hline Total number specimens & 221 & 256 & 108 & 134 & 135 & 358 & 262 \\
\hline Total number species & 26 & 28 & 21 & 28 & 22 & 33 & 26 \\
\hline
\end{tabular}

